\title{
Interplay between Epstein-Barr virus infection and environmental xenobiotic exposure in cancer
}

\author{
Francisco Aguayo ${ }^{1 *}$ (D), Enrique Boccardo ${ }^{2}$, Alejandro Corvalán ${ }^{3}$, Gloria M. Calaf $f^{4,5}$ and Rancés Blanco ${ }^{6}$
}

\begin{abstract}
Epstein-Barr virus (EBV) is a herpesvirus associated with lymphoid and epithelial malignancies. Both B cells and epithelial cells are susceptible and permissive to EBV infection. However, considering that $90 \%$ of the human population is persistently EBV-infected, with a minority of them developing cancer, additional factors are necessary for tumor development. Xenobiotics such as tobacco smoke (TS) components, pollutants, pesticides, and food chemicals have been suggested as cofactors involved in EBV-associated cancers. In this review, the suggested mechanisms by which xenobiotics cooperate with EBV for carcinogenesis are discussed. Additionally, a model is proposed in which xenobiotics, which promote oxidative stress (OS) and DNA damage, regulate EBV replication, promoting either the maintenance of viral genomes or lytic activation, ultimately leading to cancer. Interactions between EBV and xenobiotics represent an opportunity to identify mechanisms by which this virus is involved in carcinogenesis and may, in turn, suggest both prevention and control strategies for EBV-associated cancers.
\end{abstract}

Keywords: Epstein-Barr virus, environmental, cancer

\section{Introduction}

Approximately $13 \%$ of the cancer burden worldwide is etiologically related to viral infections with variations depending on sociodemographic factors $[1,2]$. The longterm persistence of viral genomes in the host is a requisite for virus-driven cancer [3, 4]. To date, viruses from only six families are recognized as carcinogens in human beings. These includes several types of human papillomavirus (HPV, Papillomaviridae), two members of the Herpesviridae family, Epstein-Barr virus (EBV; Herpesviridae) and human herpesvirus 8 (HHV-8), Hepatitis B virus (HBV, Hepadnavidae), the flavivirus Hepatitis C virus (HCV), Merkel cell polyomavirus (MCPV, Polyomaviridae), and the retroviruses human $\mathrm{T}$ lymphotropic virus 1 (HTLV-1) and human immunodeficiency virus 1 (HIV). EBV, discovered in 1964, is a DNA virus that

\footnotetext{
* Correspondence: fraguayog@academicos.uta.cl

'Universidad de Tarapacá, 1000000 Arica, Chile

Full list of author information is available at the end of the article
}

persistently infects approximately $90 \%$ of the world population [5]. This virus establishes latent persistent infections in B cells and is transmitted via nasopharyngeal secretions [6]. Although primary infection in children is asymptomatic in most cases [7], 50\% of those who experience primary infection in early adulthood develop symptomatic infectious mononucleosis (IM) [8]. Different studies revealed that EBV causes several types of neoplasms. Infection with this virus has been associated with Hodgkin's lymphoma (HL), extranodal natural killer/T lymphocytes (NK/T) cell lymphoma, and other lymphoproliferative disorders [6]. It has also been established that EBV is associated with epithelial tumors, such as nasopharyngeal (NPC) and gastric carcinomas (GC) $[9,10]$. Additionally, EBV has been detected in a proportion of oral, breast and cervical cancers, although the etiological role of the virus in these malignancies is, at present, controversial [11]. While most of the human population is persistently infected by EBV, only a small 
proportion of subjects finally develop EBV-associated tumors, suggesting that additional factors are necessary for the development of disease. Early studies reported that some environmental contaminant xenobiotics can cooperate with EBV to induce peripheral blood lymphocyte (PBL) transformation with increased EBV genome amplification in carcinogen-treated cells [12]. During the last decades, results from different studies established that xenobiotics such as tobacco smoke (TS) compounds, pollutants, food chemicals, and pesticides, among others, may be involved in EBV-associated cancers. Oxidative stress (OS) promoted by some xenobiotics alters EBV gene expression profile and host interactions, both involved in cancer. In this review, we present epidemiological and experimental evidence addressing the interplay between xenobiotics and EBV for carcinogenesis. Additionally, we suggest general mechanisms by which xenobiotics can modulate the EBV replicative cycle during epithelial or lymphoid carcinogenesis.

\section{Epstein-Barr virus: structure and replicative cycle}

Epstein-Barr virus (EBV), also known as human herpesvirus 4 (HHV-4), is a gamma-herpesvirus of the Lymphocryptovirus (LCV) genus [6]. The virus is approximately 122 to $180 \mathrm{~nm}$ in diameter with a genome composed of a linear double-stranded DNA of approximately 172,000 base pairs packed into an icosahedral capsid containing 162 capsomers. The major capsid protein is the Viral Capsid Antigen (VCA) and the minor capsid proteins are BDLF1 and BORF1 [13]. In addition, the tegument structure, located between the capsid and envelope, includes at least 17 viral proteins needed during the early stages of infection [14]. The envelope is composed of 12 glycoproteins although the fusion machinery is formed by the glycoprotein $\mathrm{B}(\mathrm{gB})$, the heterodimeric complex $\mathrm{gH} / \mathrm{gL}$, and non-conserved receptor-binding proteins [14]. EBV infection is especially targeted to B cells and epithelial cells. In fact, the EBV replicative cycle has been extensively studied in B cells where the virus establishes latency. Eventually, under conditions of B cell differentiation to plasma cells, it can be reactivated with viral maturation, releasing, and cell lysis.

The EBV replicative cycle in epithelial cells is less understood, at least in part due to the historical absence of an in vitro model for efficient viral replication, although a system based on organotypic epithelial cell cultures for EBV replication was recently established [1517]. Using this model, it was demonstrated that EBV replicates and induces cytopathic effect in oral keratinocytes from the suprabasal layers of stratified epithelium. Cells sustaining EBV amplification expressed both productive-cycle proteins and latency-associated proteins. However, no cells expressing exclusively latency genes were observed [16]. Indeed, latent EBV infection is uncommon and rarely found in normal tissues such as primary nasopharyngeal and oral epithelial cells where EBV only establishes a lytic cycle [18-20]. Interestingly, latently infected epithelial cells are detected in tonsil explants in the presence of acyclovir, albeit in less than $0.01 \%$ of cells [21].

Although EBV entry in B cells occurs through endocytosis and subsequent membrane fusion [22], EBV entry in epithelial cells is achieved through direct fusion with the cell membrane, which is carried out by the core fusion machinery composed of the $\mathrm{gB}$ and the receptorbinding complex gH/gL [22]. Furthermore, gp350 is required for efficient EBV attachment through the binding to complement receptor type 2 (CR2/CD21), which is expressed in both $\mathrm{B}$ cells and tonsillar epithelial cells [23]. The gp42 viral protein is important for B cell entry, therefore the level of this protein in the virion determines EBV tropism [24, 25]. The exact mechanism and receptors involved in epithelial cell entry have remained elusive, although members of the integrin family of proteins, such as $\alpha v \beta 5$ or $\alpha v \beta 6$, have been suggested as epithelial receptors [26]. However, blocking these integrins does not completely abolish EBV epithelial entry, suggesting that additional molecules are involved [26]. Indeed, it was reported that Ephrin receptor tyrosine kinase A2 (EphA2) works as an EBV receptor in gastric cancer epithelial cells $[27,28]$. Once the virus enters the cytoplasm, the tegument proteins and virally encoded RNAs are released. The viral genome enters the nucleus, circularizes and remains as an intranuclear episome [29]. In the nucleus, the virus tethers to the host genome through the Epstein-Barr Nuclear Antigen (EBNA1) [30], which in turn, is involved in DNA replication by the host DNA polymerase through binding to the OriP site during latency. In general, multicopies of the EBV genome are heterochromatinized by the host cell machinery [29]. The BNRF1 viral protein binds to DAXX protein forming a complex to suppress transcription through histone methylation [31]. Besides, BZLF1 transcripts packaged into the virions are immediately translated (1,5 h after infection) to initiate the pre-latent abortive lytic phase of infection. During this phase, the classical latency genes are expressed: Epstein-Barr nuclear antigens (EBNAs), latent membrane proteins $(L M P s)$, viral non-coding RNAs and microRNAs, and some lytic genes such as BZLF1 and BRLF1. This transient phase ends after 1- 2 weeks and virion generation does not occur [32]. Then, according to the expression profile, EBV establishes four types of latency in a cell type- and phenotype-dependent manner. Latency 0 is established in periphery resting $B$ cells (EBERs and BARTs); latency I is established in periphery dividing B cells and Burkitt's lymphoma (EBERs, BARTs and EBNA1); latency II is established in B cells from tonsil 
germinal center and Hodgkin's lymphoma (EBERs, BARTs, EBNA1, LMP1, LPM2A, and LMP2B) and finally, latency III is established in tonsil naïve B cells and immunoblastic lymphoma (EBERs, BARTs, LMP1, LMP2A, LMP2B, EBNA1, EBNA-LP, EBNA2, EBNA3A, EBNA3B and EBNA3C) [33-35]. Latency I/II is clearly detected in tumor epithelial cells, including GC and NPC [36, 37].

Factors related to the differentiation of B lymphocytes or epithelial cells are strongly related to activation of the lytic cycle. This is a highly regulated process currently divided into three phases: Immediate-early (IE), early (E), and late $(\mathrm{L})$. The switch from latency to lytic cycle involves the expression of the BZLF1 and BRLF1 genes, regulated by the $\mathrm{Zp}$ and $\mathrm{Rp}$ promoters, respectively $[32,38]$. The encoded products, Zta and Rta proteins, are transcription factors that regulate EBV early lytic cascade. It has been suggested that Blimp1, expressed during terminal differentiation of epithelial cells, is important for Zp promoter activation, enabling lytic cycle induction [39]. Additionally, chemicals such as 12-O-tetradecanoylphorbol-13-acetate (TPA), sodium butyrate and calcium ionophores induce the EBV lytic cycle, whereas epigenetic modifications such as DNA methylation and histone deacetylation are related to inhibition of IE gene transcription [40]. In any case, the expression of both Zta and Rta proteins is always required for subsequent expression of lytic early proteins [41] such as BMRF1, SM, BHLF1, and BHRF1. Additionally, viral DNA polymerase (BALF5) [42], the DNA polymerase processivity factor (BMRF1) [43], the viral helicase (BBLF4) [44], and viral primase (BSLF1) [44], among others are currently expressed at this stage. BMRF1 and BRRF1 are transcription factors that activate the oriLyt (Lytic replication origin). The oriLyt has a complex structure containing multiple regions required for DNA replication which is executed by the viral BALF5 DNA polymerase [45]. The viral DNA replication occurs through a rolling circlemechanism leading to the formation of concatemers which are finally cleaved and packaged $[46,47]$. Once the viral DNA is replicated, late lytic genes are expressed, but the manner in which EBV late promoters are regulated is poorly understood. The late genes encode for structural proteins including nucleocapsid and glycoproteins on the viral envelope (gp350/220, gp85, gp42, and gp25). In oral epithelial cells, both late gene expression and viral maturation (lytic cycle) occur in the upper differentiated layer of stratified epithelia [17].

\section{Role of EBV in epithelial and lymphoid cancers Nasopharyngeal carcinomas}

NPC is a rare type of head and neck cancer arising in the nasopharynx [48] and frequently occurring in certain populations from Central Africa or Asia [49]. In all likelihood, factors related to lifestyle or sociodemographic features are relevant in the development of this tumor $[48,49]$. There are three histological types: type 1: squamous cell carcinoma; type 2: non-keratinizing carcinoma; and type 3: undifferentiated carcinoma [50]. Nearly $100 \%$ of undifferentiated NPCs, the most frequent histological type, harbor episomal copies of EBV, suggesting that this viral infection is a necessary condition for its development [9]. EBV is able to regulate multiple signaling pathways which include NF-kB, PI3K/Akt/ mTOR, Wnt/B-catenin and JAK/STAT for NPC development (reviewed in [51]). In addition, EBV directly inhibits some tumor suppressors including p53 [52, 53], while indirectly reducing the expression of other tumor suppressor genes by promoting hypermethylation [54, 55]. Although EBV establishes a latency II type in NPC, abortive lytic reactivation has been detected, suggesting that early gene activation from the $\mathrm{Zp}$ promoter is relevant for nasopharyngeal carcinogenesis [56, 57]. In particular, EBNA1 enhances the activator protein-1 (AP-1) pathway promoting angiogenesis [58], and the expression of the zinc finger E-box binding homeobox 1 (ZEB1) and ZEB2 genes, promoting EMT in NPC cells [59]. Additionally, LMP1 activates NTRK2mediated AKT/ERK signaling pathway promoting EMT [60]. Cai et al. (2015) also demonstrated the capacity of EBV-miRBART7-3p to promote EMT, migration and metastasis in NPC cells [61]. LMP1 increases angiogenesis by promoting VEGF expression through the JNKs/c-Jun signaling pathway [62]. Moreover, LMP1 induces the binding of NF-kB p65 to the human telomerase reverse transcriptase (hTERT) and the subsequent translocation of these proteins from the cytoplasm to the nucleus [63]. LMP1 also induces the expression of the programmed death ligand-1 (PDL-1) in NPC cells, which plays an important role in immune evasion [64]. BARF1 was able to cooperate with $\mathrm{H}$-ras for inducing anchorage-independent growth as well as tumor formation in nude mice [65]. Furthermore, the EBV-encoded mi-RNAs (miR)-BART19-3p decreased apoptosis in NPC cells [66], while miR-BART5 diminished the mRNA level of the proapoptotic PUMA [67]. Similarly, EBV-miR-BART8-3p promotes NPC cell migration and metastasis via NF- $\mathrm{kB}$ and ERK1/2 pathways [68].

\section{Gastric cancer}

$\mathrm{GC}$ is the third leading cause of cancer-related deaths worldwide and ranks fifth in relation to number of cases per year [69]. Its development is believed to be the result of a complex interaction between environmental, genetic and nutritional factors [70]. Among high-risk factors, $H$. pylori and EBV infection, tobacco smoking, alcohol consumption, and low intake of fruits and vegetables are considered to play a key role in GC development [71]. In 1990, Burke and co-workers reported the association between EBV and GC with lymphoepithelioma-like histology for the first time [72]. Shortly after, it was also demonstrated that genomic sequences of EBV were 
present in a subset of typical gastric adenocarcinoma [73]. Multiple EBV genomes were present in the GC cells, based on the intensity of DNA by in situ hybridization (ISH) signals and PCR dilution studies [73]. Epstein-Barr virus-encoded small RNAs (EBERs) are the most abundant RNAs present in infected cells and interact with several host proteins to form ribonucleoproteins complex (RNP). The prevalence of EpsteinBarr virus (EBV)-associated gastric carcinoma (EBVaGC) is between $5.0-17.9 \%$ worldwide [74], although Latin America shows a high incidence of EBVaGC [10]. It has been found that the LMP1 oncogene, overexpressed in all EBV-associated lymphomas, is poorly or nonexpressed in EBVaGC. The main viral protein whose expression is retained during EBV latency is EBNA1, which has been characterized as an oncoprotein [75]. In addition, BARF1 is expressed in the majority of EBVaGC cases [76].

\section{Hodgkin lymphoma}

Hodgkin lymphoma (HL) or Hodgkin's disease accounts for up to $20 \%$ of all lymphomas depending on demographic factors [77-79]. HL is composed of two pathological types: Classic HL and nodular lymphocyte predominant HL (NLPHL) which show different etiopathogenesis [80]. HL is heterogeneous being composed by mononuclear Hodgkin cells, Reed-Stemberg (RS) cells, with an inflammatory infiltrate composed by $\mathrm{B} / \mathrm{T}$ cells, plasma cells, histiocytes, neutrophils, eosinophils and mast cells [81]. The prevalence of EBV in HL shows sociodemographic differences [82, 83], although evidence suggests that age of primary EBV infection and acute IM are risk factors for this malignancy $[80,83]$.

\section{Burkitt lymphoma}

Burkitt Lymphoma (BL) is an aggressive non-Hodgkin lymphoma (NHL) affecting B cells. Although the oncogenic mechanisms are unclear, BL is characterized by c-MYC gene translocation on chromosome 8 in a very high percentage of cases. This alteration leads to c-Myc protein overexpression [84]. Besides, this lymphoma is associated with EBV and HIV infection. In view of the involvement of different etiological factors, BL is classified as endemic (eBL), sporadic (sBL), and immunodeficiency-related [85]. The association of BL with EBV infection is widely reported. In fact, EBV was first identified in a BL sample of a patient from the equatorial Africa in the 1960s. Since then, different studies have established the clear association of EBV and sociodemographic, environmental and geographical factors in BL etiopathogenesis [86]. Early on, it was observed that areas with high incidence of endemic cases of BL in Sub-Saharan Africa and Papua New Guinea exhibited a striking overlap with areas with holoendemic malaria [85, 87]. Importantly, 95\% of eBL cases in these regions are associated with EBV infection.
Moreover, the average age of diagnosis is under 7 years, making eBL a leading cause of childhood malignancies in these parts of the world. On the other hand, sBL exhibits a significantly different incidence profile. It is the most common variant in Northern Africa, Europe, and North America. In these regions, this tumor is still common in children, accounting for almost one-third of all pediatric lymphomas. These lymphomas correspond to $1 \%$ to $5 \%$ of all NHL in adults $[88,89]$ representing a substantial proportion of all sBL diagnosed [89, 90]. The median age of incidence of sBL is 30 years [91] with peaks of incidence reported at 10 and 70 years of age $[89,92]$. Another important characteristic of sBL is that only $20 \%$ to $40 \%$ of the cases are positive for EBV DNA [93]. Finally, immunodeficiency-associated BL, the third BL clinical category, is diagnosed in immunosuppressed patients either infected by HIV or transplant organ recipients [93]. The data briefly presented above highlight the complex interactions between genetic, geographical, social, environmental, and viral factors that cooperate in the development of BL. An in-depth discussion of these factors, the cellular signaling pathways involved, the viral genes involved in evasion and cell transformation exceeds the scope of this review. To obtain insights into the mechanisms involved the reader is referred to some excellent studies [34, 94-97].

\section{Lymphoepithelial carcinoma}

Lymphoepithelial carcinoma (LEC), also called lymphoepithelioma-like carcinoma, is a rare high-grade tumor characterized by an undifferentiated carcinoma, accompanied by a non-neoplastic lymphoplasmacytic infiltrate [98]. LECs are considered as non-keratinizing squamous cell carcinomas similar to NPC (undifferentiated type) that arise in locations other than the nasopharynx $[98,99]$. LEC commonly develops in the head and neck regions $[100,101]$, but are also diagnosed in other organs with epithelial lining [102-104]. EBV infection was detected in $87.5 \%$ of head and neck LEC [100]. Of note, this virus was found in $96.1 \%$ of the salivary gland LEC [101]. In pulmonary LEC, EBV infection was evidenced in up to $93.8 \%$ of samples and it was significantly increased when compared with non-LEC [102]. Similarly, the expression of EBV was found in $86.4 \%$ of gastric LEC, which was also significantly higher compared with the non-LEC group [103].

\section{EBV in other epithelial tumors}

Cervical cancer is the fourth most commonly diagnosed tumor in women and the fourth cause of cancer-related death for this gender [105]. The etiological association of HPV infection with cervical cancer is well established [106]. However, less than $5 \%$ of infected women develop this disease [107], suggesting that other factors (e.g. TS, use of oral contraceptives, viral coinfection) are involved in cervical carcinogenesis. In this regard, HPV/EBV co-presence was found 
in epithelial cells from cervical carcinomas, ranging from $27.8 \%$ to $100 \%$. Moreover, the frequency of EBV infection increased with the grade of the cervical lesion [108]. In cervical cancer, the expression of LMP1 and EBNA2 latent proteins was evidenced [109], which is consistent with the establishment of latency III program. Interestingly, the expression of LMP1 and EBNA1 latent proteins accompanied by BARF1 was also detected in cervical cancer [110]. However, the role of EBV in the development and/or progression of cervical tumors is still under discussion (Reviewed in [111]).

Breast cancer ranks first in both incidence and cancerrelated death in women worldwide [105]. A variety of risk factors have been related to the development of breast tumors, including but not limited to, family history, diet, hormone use, alcohol consumption, and TS [112]. Some oncogenic viruses such as HPV, EBV, human cytomegalovirus (HCMV), bovine leukemia virus (BLV), and mouse mammary tumor virus (MMTV) have been identified in breast cancer [113-116]. In particular, a meta-analysis found an overall prevalence of EBV in 26\% (ranging from 0 to $78 \%$ ) of breast carcinomas, which suggests a potential contribution of EBV to the development of these tumors [117]. Additionally, EBV infection of immortalized human mammary epithelial cells increased the tumor formation in NOD/SCID mice. EBV-related tumors displayed a latency II type, characterized by EBNA1 and LMP1-2B expression accompanied by $B X L F 2$ and $B F R F 3$ lytic gene expression [118]. Additionally, EBNA1, LMP1, BZLF1, and $B A R F 1$ transcripts were detected in breast carcinoma samples [119]. Nonetheless, the evidence is insufficient to establish an etiological role of EBV in breast cancer (reviewed in [120]).

Colorectal carcinoma ranks third in incidence worldwide, being the second cause of cancer-related death in both genders [105]. Family history of colorectal cancer or adenomatous polyposis, increased intake of red and processed meats, obesity, alcohol use, and TS are all among the risk factors associated with this cancer [121, 122]. Additionally, oncogenic viruses such as HPV, $\mathrm{JCPyV}, \mathrm{BKPyV}$ and EBV have been detected in colorectal cancers (reviewed in [123]). In particular, the frequency of EBV infection in colorectal carcinoma ranges from $0 \%$ to $46 \%$ [124]. EBNA1 and $L M P 1$ gene expression was detected in $14 \%$ and $25 \%$ of colorectal carcinomas, respectively. Moreover, LMP1 protein expression was associated with grade 2 adenocarcinoma [125]. Conversely, an association between EBV DNA with CPG island methylation was not detected in colorectal carcinomas [126]. Therefore, the potential role of EBV in colorectal cancers warrants further investigation.

\section{EBV Abortive lytic cycle}

EBV role in cancer involves restrictions of complete lytic cycle activation, several studies have reported the significance of the expression of some lytic genes. The abortive lytic cycle occurs when EBV is maintained in a latent physical status with partial expression of lytic genes. The term "abortive" means that viral maturation does not occur because structural late genes are not expressed, and thus the infected cells are not lysed as normally occurs during a complete lytic cycle. Previous reports demonstrated the expression of some EBV lytic genes in epithelial cancers and EBV-associated lymphomas [127]. Zta protein was expressed in 100\% nasopharyngeal carcinomas, suggesting that this IE protein is relevant in this malignancy [128]. Other studies confirmed this finding as well as the coexistence of latent and lytic gene expression in NPC [56, 129]. What's more, there is solid experimental evidence that the EBV abortive lytic cycle is important for carcinogenesis [127, 130, 131]. For instance, knock-out mice for BZLF1 (encoding for Zta protein) and BRLF1 (encoding for Rta protein) genes are unable to efficiently induce lymphoproliferative disease, demonstrating that lytic genes are involved in these malignancies [132]. Moreover, an EBV mutant with enhanced Zta expression causes abortive lytic infection and lymphomas in a humanized mouse model [133]. Regarding epithelial cancers, it was observed that EBV lytic reactivation induced by TPA and sodium n-butyrate is critical for promoting genomic instability, thereby increasing the tumorigenic potential [134]. Importantly, the lytic viral protein BGLF5 was found to have the most significant effect in promoting DNA damage, genomic instability, increased cell migration, and repression of host repair-related enzymes [135]. Furthermore, expression of BALF3, the product of an EBV late gene, increased genomics instability and tumor properties of NPC cells [136]. However, the factors and mechanisms leading to abortive lytic cycle establishment are unclear.

\section{Xenobiotics in EBV-driven cancers \\ Tobacco smoke increase EBV antibodies suggesting an increased viral load}

The International Agency for Research on Cancer (IARC, Lyon, France) has declared TS as a class 1 carcinogen in humans [137]. Extensive studies addressing molecular mechanisms and signaling pathways involved in epithelial carcinogenesis associated to TS (i.e., lung, oral cavity, esophagus, etc.) have been previously published [138-140]. More than 4,500 chemical compounds have been identified in TS, 73 of which have demonstrated carcinogenic potential [141]. These include aromatic polycyclic hydrocarbons such as benzo $[\alpha]$ pyrene (BaP), N-nitrosamines, benzene, aldehydes, and 1,3-butadiene, among others (Figure 1). Previous epidemiological and experimental studies have shown complex and multi-level interactions between TS components and 
some viral infections. For example, TS is a cofactor in cervical carcinogenesis induced by human papillomavirus (HPV) (reviewed in [111]). Cooperation between TS and Hepatitis B virus [142] or Hepatitis C virus for developing liver cancer, has also been suggested [143].

Early studies demonstrated that tobacco-derived nitrosamines requiring metabolic activation $\mathrm{N}^{\prime}$-nitrosonor nicotine (NNN) and 4-[methylnitrosamino]-1-[3-pyridyl]-1- butanone (NNK) increased both EBV-induced lymphocyte transformation and EBV genomes load [12]. Interestingly, epidemiological studies have suggested that TS is involved as a cofactor in EBV-mediated cancers, including B cell lymphomas, GCs, and NPCs [144-146]. Indeed, Camargo and co-workers (2014) demonstrated that smoking association with GC is higher for EBVpositive than for EBV-negative tumors [144]. The authors suggested that the interaction of smoking with EBV-positive GC may occur by EBV reactivation from latency, as occur in EBV-positives cell lines Akata and B95-8 [147]. However, additional mechanisms may be involved, and we cannot deny the possibility of additive effects of smoking with EBV. Other studies have reported positive associations between TS exposure and risk of EBV-related Hodgkin lymphoma in women from the United States $[148,149]$. Additionally, some reports found a positive relationship between smoking and NPC risk [150-152] which involved elevated levels of EBV antibodies in NPC patients [153-155]. A recent study described an association between serum cotinine levels and positivity for EBV serological markers in healthy men from China [156]. Another study found that TS promotes EBV replication with viral maturation (increased gp350, a lytic late protein) in lymphoblastic cells [147]. Taken together, these findings suggest that TS components promote EBV lytic reactivation with increased viral load and dissemination [156]. Conversely, no association between EBV VCA detection, DNA viral load or EBV serology and smoking status in a cohort of 313 male subjects was reported, suggesting that TS is not related to viral lytic replication in the nasopharynx [157]. Therefore, additional studies are necessary to better understand the potential role of TS in the EBV replicative cycle.

As previously stated, EBV establishes a lytic cycle in normal epithelial cells $[18,20]$. It has been hypothesized that previous genetic alterations are required for promoting EBV genome maintenance and latency establishment in epithelial cells $[158,159]$. In fact, TS components themselves promote DNA damage and activation of DNA damage response (DDR) [160, 161]. Additionally, Cyclin D1 overexpression is frequently found in EBV-infected dysplastic nasopharyngeal epithelial tissues, promoting cell proliferation and clonal expansion [162]. Moreover, Cyclin D1 overexpression can override growth inhibition and cellular senescence promoted by EBV infection [162, 163]. The same authors previously reported that $C D K N 2 A$ (p16) gene loss through homozygous deletion is a frequent alteration in NPC [164]. Interestingly, TS compounds promote these molecular alterations in different cellular models and smoker subjects, suggesting the possibility that TS may be involved in promoting the EBV genome maintenance and consequently, the latency establishment in epithelial cells [165-169]. This is an interesting possibility to be addressed in future studies. Taken together, it is plausible that TS compounds are directly involved in long-term EBV propagation in epithelial cells, with a role in cancer initiation. Additional experimental approaches are needed to dissect the specific role of TS in EBVassociated carcinogenesis.

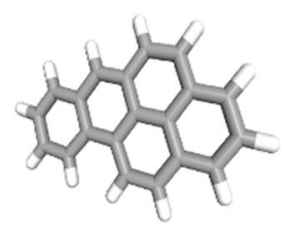

Benzo[a]pyrene

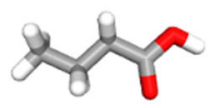

Sodium butyrate

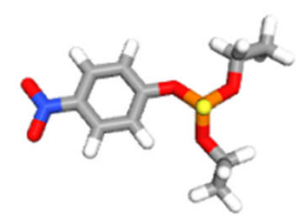

Parathion

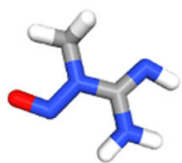

$\mathrm{N}$-methyl-N-nitrosoguanidine

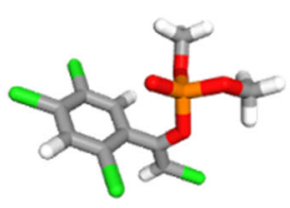

Tetrachlorvinphos

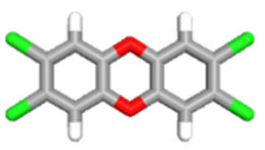

2,3,7,8-Tetrachlorodibenzo-p-dioxin

Fig. 1 Environmental xenobiotics structure. Tobacco smoke component: benzo (a) pyrene; pesticides: Parathion, tetrachlorvinphos; Food chemicals: sodium butyrate, $\mathrm{N}$-methyl-N-nitrosoguanidine and, 2,3,7,8-tetrachloroddibenzo-p-dioxin. 


\section{Pesticides}

Many studies have evaluated the relationship between pesticide exposure and the development of diverse hematological (i.e., lymphoma) or epithelial (i.e., breast) tumors [170-173]. In fact, the IARC classified malathion and diazinon as "probably carcinogenic" (group 2A), and parathion and tetrachlorvinphos as "possibly carcinogenic" (group 2B) (Figure 1) [174]. In particular, organophosphorous pesticides like parathion and malathion have been used extensively to control mosquito plagues and a wide range of sucking and chewing pests that target field crops, fruits, and vegetables. It has been considered that reactive oxygen species (ROS) are caused by such substances which may be involved in the toxicity of various pesticides. Studies have shown that catechol formation is a risk factor for breast cancer since it gives rise to quinones that cause DNA damage and generate ROS which promote oxidative damage [175]. Some organophosphate insecticides are also used as herbicides, the most successful example is glyphosate, which is consumed by humans through food products and can be detected in urine, serum, and breast milk samples. It is considered dangerous to the population according to IARC (2015) which declared it as "possibly carcinogenic" [176]. However, studies evaluating a potential relationship between pesticide/herbicide exposure and EBV infection in cancer, are scarce. Of note, it was reported that chlorpyrifos (CPF), a common organophosphate (OP) pesticide, can promote EBV lytic cycle activation through OS in lymphoblastic cells. Besides, lytic cycle activation occurred by increasing BZLF1 levels in a CPF dose-dependent manner [177]. Organochlorines, frequently used as pesticides, enhance the expression of EBV early antigens (EA), promoting lytic infection and increasing the risk of NHL [178-180]. In addition, an increased risk of hairy cell leukemia (HCL) in an organochlorine dose dependent-manner was found in subjects with increased EBV EA IgG, suggesting a functional cooperation between EBV and organochlorines [181]. Moreover, extranodal natural killer (NK)/T-cell lymphoma nasal type (NNKTCL), which is etiologically associated with EBV infection [182-185], was found to be related to pesticides and exposure to some chemical solvents, which suggests the possibility of EBV/pesticide cooperation in this malignancy [186].

As previously mentioned, EBV infection has been implicated in $95 \%$ of eBL cases from high-risk regions and less than $30 \%$ from low-risk regions (sBL) [187]. The role of pesticides in pediatric eBL and $\mathrm{sBL}$ is not clear. Only some studies addressed pesticide exposure as a risk factor for $\mathrm{BL}$ or $\mathrm{HL}$ and established associations with age or demography. One study reported that, pesticide use was associated with increased risk of developing childhood hematological diseases, including $\mathrm{HL}$ and
NHL [188]. Additionally, Latifobic L et al (2020) reported that association between pesticide exposure and HL was higher in subjects less than 40 years [189]. Interestingly, maternal exposure to insecticides in France (OR 1.6, 1.3-2.1, 95\% IC) was related to an increased risk of NHL and HL during childhood [190]. Conversely, one study in Great Britain did not support the notion that parental pesticides or solvent hydrocarbon exposure increase the risk of childhood lymphoma [191], and no evidence of elevated risk associated with residential proximity at birth to agricultural use land for most childhood cancers was observed in Texas, US [192].

Taken together, considering experimental and epidemiological findings, it is possible to speculate a potential role of pesticides in the promotion of EBV reactivation during leukemia/lymphoma development.

\section{Environmental pollutants}

It has been determined that high concentrations of persistent organic pollutants (POP) such as polychlorinated biphenyls (PCB), hexachlorobenzene ( $\mathrm{HCB})$, and some chlordanes (Figure 2) were associated with increased IgG antibodies to EBV early antigens in patients with NHL. These findings suggest the possibility that POP exposure might be related to EBV reactivation in NHL patients with a subsequent increase in EBV antibodies [193]. Furthermore, it was shown that prolonged exposure to some chemical compounds such as H2S, NH3, SO2, HF, NO2, chlorides, nitroesters, and dust significantly increased EBV IgG/IgM antibodies in chemical factory employees when compared with non-exposed blood donors. Moreover, enhanced immunological disturbances and hepatopathies were observed in the group of exposed subjects [194]. Thus, these findings suggest an increase in EBV lytic activation through persistent environmental contaminants.

\section{Food chemicals}

Dioxins are persistent contaminant polyhalogenated dibenzo-p-dioxins such as 2,3,7,8-tetrachlorodibenzo-pdioxin (TCDD) from diverse environmental sources with bioaccumulation in the food chain (Figure 1) [195]. Approximately $90 \%$ of dioxins-like compound exposure occurs through ingestion of contaminated food, such as fish, meat, eggs, or milk, among others [196, 197]. In 1976, after an industrial accident in Italy in which workers were acutely exposed to TCDD, a high frequency of epithelial and lymphoid cancers was observed [198]. Mechanistically, there is evidence that activation of the aryl hydrocarbon receptor (AhR) upon TCDD binding leads to BZLF1 gene expression and EBV reactivation in both $B$ cells and salivary epithelial cells, which shows potential consequences in autoimmune diseases and cancer [199]. In fact, canonical AhR activation 

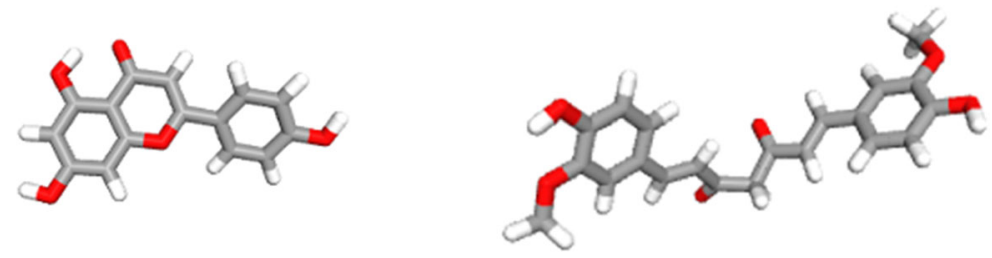

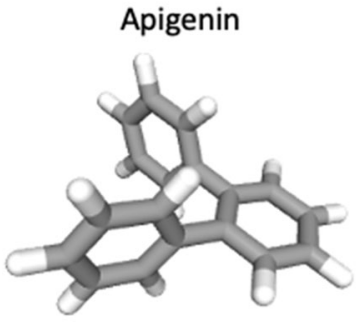

Terphenyl
Curcumin

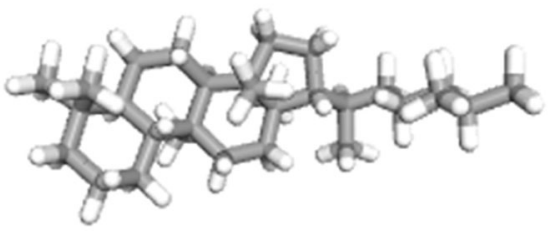

Cucurbitane

Fig. 2 Structure of natural compounds (Apigenin, curcumin, terphenyl and cucurbitane) with inhibitory effects in EBV replication and EBV-driven cell proliferation.

involves binding to lipophilic agonists (xenobiotics) which diffuse through the plasma membrane, subsequently binding to $\mathrm{AhR}$ nuclear translocator protein (Arnt) with the complex being translocated to the nucleus for DNA binding. The AhR/Arnt complex binds the xenobiotic-response elements (XRE) located in the promoter regions of several genes and modulate their expression [200]. In particular, Phase I (CYP1A1) and Phase II (UGT1A1) enzymes are expressed upon XRE activation [201]. Additionally, it has been established that activated AhR modulates the immune response to viral infections, which varies in a cell type- and pathogen-dependent manner [202-204]. Therefore, it is possible to speculate that such alterations may be involved in the dioxin-mediated induction of EBV lytic activation and cancer development. It was also found that EBNA3, expressed during latency III in B cells, directly binds to AhR for dioxin-response element (DRE) activation. Interestingly, the presence of TCDD stabilized such EBNA3/AhR interaction. Since EBNA3 counteracts TCDD-induced cell growth inhibition in EBV-infected $B$ cells, it is suggested that EBV uses EBNA3/AhR to oppose the negative effects of dioxin/AhR interaction on cell proliferation and survival [205].

Food chemicals such as volatile N-nitrosamines and precursors as well as host-related factors are also associated with NPC development [206]. Volatile N-nitrosamines are present in foodstuffs (i.e., Chinese salted fish) and preserved food from areas with a high prevalence of NPC [207-209]. Nmethyl- $\mathrm{N}^{\prime}$-nitro-N-nitrosoguanidine (MNNG, a nitrosamide) was reported to increase EBV reactivation (Figure 1) [210]. In addition, a mixture of MNNG, 12-O-tetradecanoylphorbol13-acetate (TPA) and sodium butyrate significantly increased the genomic instability and invasiveness of EBV positive NPC cells, suggesting cooperation between compounds for EBVmediated carcinogenesis [210]. Different studies have also confirmed an increased risk of NPC in North Africa associated with rancid butter, rancid sheep fat, and quaddid consumption. For instance, a role was suggested for butyric acid, which is released by hydrolysis from glyceride when butter becomes rancid [211]. Furthermore, it was demonstrated that aflatoxin B1 (AFTB1), a mycotoxin present in some agricultural crops (i.e., wheat, maize, and nuts), increased EBVmediated PBL transformation and EBV genomes per cell [12]. Accordingly, Accardi and co-workers (2015) showed that AFTB1 increased EBV replication and viral load in primary and immortalized B cells. Moreover, it was discovered that AFTB1-mediated BZLF1 expression requires phosphatidylinositol 3-kinase (PI3K) signaling pathway activation [212]. Conversely, incubation with N-acetylcysteine, an oxygen-free radical scavenger, reduced EBV reactivation, demonstrating the role of OS in promoting the EBV lytic cycle. In addition, curcumin, a known antioxidant polyphenol derived from Curcuma longa with antitumor and antioxidant properties, inhibited the proliferation of EBV-positive NPC cells by decreasing the expression of EBNA1 [213]. In fact, there is evidence that this natural compound rescues tumor cells from epithelial-mesenchymal transition (EMT), suggesting a potential therapeutic utility $[214,215]$. Other natural compounds such as cucurbitane glycosides from the fruits of Siraitia grosvenorii (monk fruit) showed inhibitory effects on EBV reactivation (Figure 2). Importantly, the flavonoid apigenin suppressed the activity of the EBV Zp and Rp promoters, as demonstrated by reporter assays. In particular, a region between -134 to -51 within the $\mathrm{Zp}$ for $\mathrm{Sp} 1 / \mathrm{Sp} 3$, MEF2D, ATF-1, ATF-2 and CREB binding, was required for 


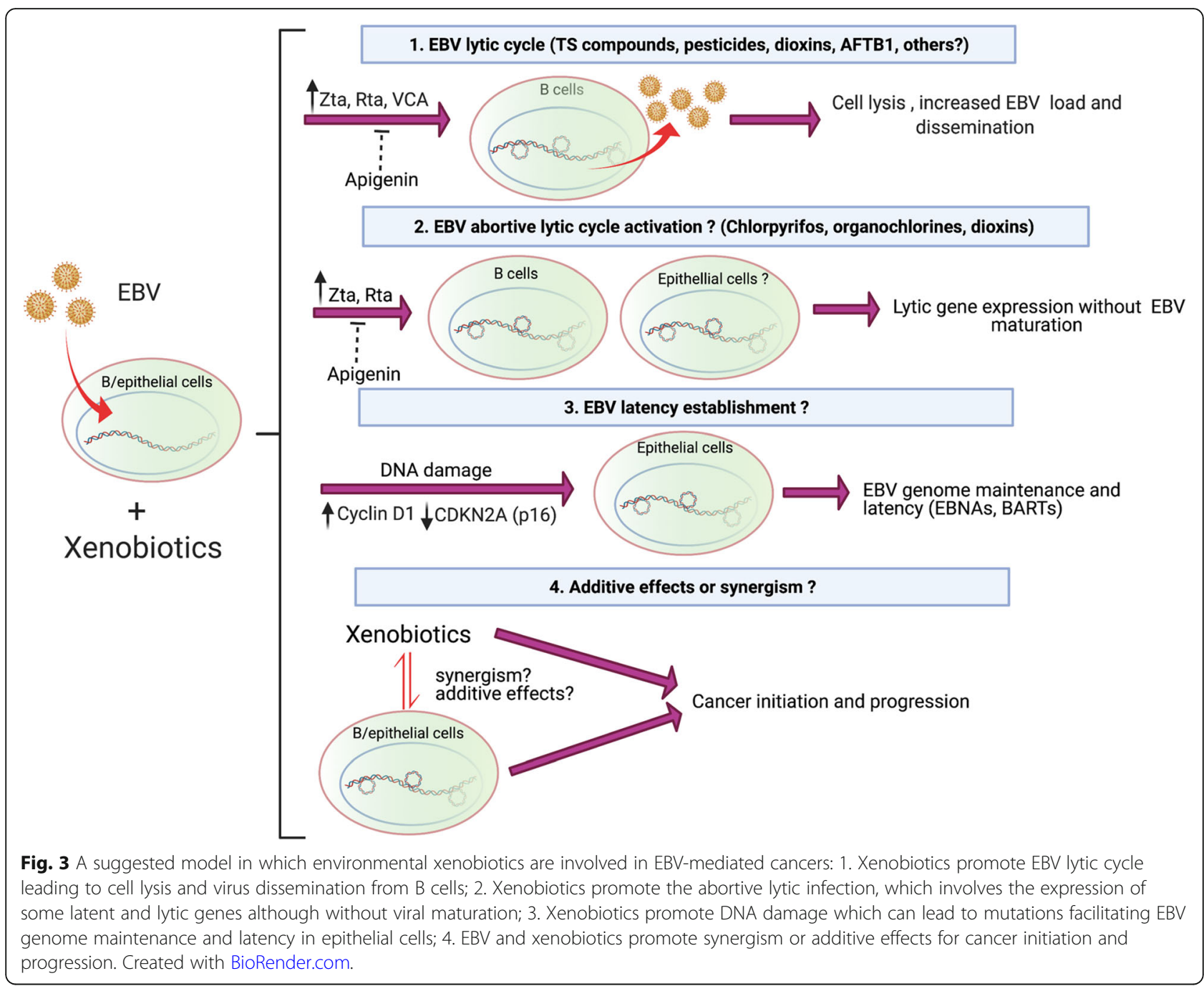

apigenin inhibition [216]. Thus, apigenin may be a potential dietary compound for prevention of EBV reactivation.

\section{Conclusions}

Xenobiotics such as those present in tobacco smoke, pollution, pesticides, and food affect the EBV replicative cycle, which can lead to cancer. Such a functional interaction could occur at different levels. First, xenobiotics are involved in EBV lytic activation leading to viral dissemination from B cells. Second, xenobiotics are involved in EBV lytic activation leading to the occurrence of abortive lytic infection, in turn promoting both lymphoid and epithelial cancer progression. Third, xenobiotics that promote OS and DNA damage could facilitate EBV genome maintenance and the establishment of latency in epithelial cells during cancer initiation. However, additional studies are warranted to confirm this possibility. Fourth, additive or synergistic effects in EBVdriven cancers with xenobiotics involved in cancer development are plausible. Therefore, considering the current knowledge about EBV/environmental xenobiotic interaction, a general model of carcinogenesis is shown in Figure 3. We cannot deny the possibility that additional mechanisms of EBV/xenobiotic interaction may be involved in carcinogenesis. Therefore, more studies are warranted to dissect such mechanisms and signaling pathways involved in EBV gene expression alterations and their interaction with xenobiotics. This knowledge will impact both prevention and therapeutic possibilities for EBV-associated cancers.

\section{Acknowledgments}

Not applicable

\section{Authors' Contributions}

"Conceptualization, FA.; writing —original draft preparation, F.A.; writing-review and editing, F.A., E.B., A.H.C, R.B. and G.M.C. The authors have read and agreed to the published version of the manuscript.

\section{Funding}

The present study was supported by FONDECYT \#1200656 (to GMC), grant UTA-MINEDUC UTA1117 (to GMC); Conicyt-Fondap 15130011 (to AHC); FAPE 
SP Grant \#2019/26065-8 (to EB) and ANID-FONDECYT Postdoctoral Grant 3190723 (to RB).

\section{Availability of data and materials}

Not applicable

\section{Declarations}

\section{Competing Interest}

None declared

\section{Ethics approval and consent to participate}

Non applicable

\section{Consent for publication}

Not applicable

\section{Author details}

'Universidad de Tarapacá, 1000000 Arica, Chile. '2Laboratory of Oncovirology, Department of Microbiology, Instituto de Ciências Biomédicas, Universidade de São Paulo, São Paulo, Brazil. ${ }^{3}$ Advanced Center for Chronic Diseases (ACCDiS), Pontificia Universidad Católica de Chile, Santiago, Chile. ${ }^{4}$ Instituto de Alta Investigación, Universidad de Tarapacá, 1000000 Arica, Chile. ${ }^{5}$ Center for Radiological Research, Columbia University Medical Center, New York, NY 10032, USA. 'aboratorio de Oncovirología, Programa de Virología, Instituto de Ciencias Biomédicas (ICBM), Facultad de Medicina, Universidad de Chile, Santiago, Chile.

Received: 10 January 2021 Accepted: 18 June 2021

Published online: 30 June 2021

\section{References}

1. de Martel C, Georges D, Bray F, Ferlay J, Clifford GM. Global burden of cancer attributable to infections in 2018: a worldwide incidence analysis. Lancet Glob Health. 2020:8:e180-90. https://doi.org/10.1016/S2214-109X(1 9)30488-7.

2. Parkin DM, Hämmerl L, Ferlay J, Kantelhardt EJ. Cancer in Africa 2018: The role of infections. Int J Cancer. 2020;146:2089-103. https://doi.org/10.1002/ ijc.32538.

3. Avanzi S, Alvisi G, Ripalti A. How virus persistence can initiate the tumorigenesis process. World J Virol. 2013;2:102-9. https://doi.org/10.5501/ wjv.v2.i2.102.

4. White MK, Pagano JS, Khalili K. Viruses and human cancers: a long road of discovery of molecular paradigms. Clin Microbiol Rev. 2014;27:463-81. https://doi.org/10.1128/CMR.00124-13

5. Epstein MA, Achong BG, Barr YM. Virus particles in cultured lymphoblasts from Burkitt's lymphoma. Lancet. 1964;1:702-3.

6. Young LS, Yap LF, Murray PG. Epstein-Barr virus: more than 50 years old and still providing surprises. Nat Rev Cancer. 2016;16:789-802. https://doi.org/1 $0.1038 /$ nrc.2016.92

7. Jayasooriya S, de Silva TI, Njie-jobe J, Sanyang C, Leese AM, Bell Al, et al. Early virological and immunological events in asymptomatic Epstein-Barr virus infection in African children. PLoS Pathog. 2015;11:e1004746. https:// doi.org/10.1371/journal.ppat.1004746.

8. Becker JA, Smith JA. Return to play after infectious mononucleosis. Sports Health. 2014;6:232-8. https://doi.org/10.1177/1941738114521984.

9. Tsao SW, Tsang CM, Lo KW. Epstein-Barr virus infection and nasopharyngeal carcinoma. Philos Trans R Soc Lond B Biol Sci. 2017;372. https://doi.org/10.1 098/rstb.2016.0270

10. Carrasco-Avino G, Riquelme I, Padilla O, Villaseca M, Aguayo FR, Corvalan $\mathrm{AH}$. The conundrum of the Epstein-Barr virus-associated gastric carcinoma in the Americas. Oncotarget. 2017;8:75687-98. https://doi.org/10.18632/ oncotarget.18497.

11. de Lima MAP, Teodoro IPP, Galiza LE, Filho PHBM, Marques FM, Pinheiro Junior RFF, et al. Association between Epstein-Barr Virus and Oral Carcinoma: A Systematic Review with Meta-Analysis. Crit Rev Oncog. 2019; 24:349-68. https://doi.org/10.1615/CritRevOncog.2019031897.

12. Henderson EE, Franks C, Fronko G. Chemical carcinogen Epstein-Barr virus (EBV) synergism: EBV genome amplification and site-specific mutation during transformation. Int J Cancer. 1989;43:72-9. https://doi.org/10.1002/ ijc.2910430116.
13. Wang WH, Chang LK, Liu ST. Molecular interactions of Epstein-Barr virus capsid proteins. J Virol. 2011;85:1615-24. https://doi.org/10.1128/JVI.01565-10.

14. Johannsen E, Luftig M, Chase MR, Weicksel S, Cahir-McFarland E, Illanes D, et al. Proteins of purified Epstein-Barr virus. Proc Natl Acad Sci U S A. 2004; 101:16286-91. https://doi.org/10.1073/pnas.0407320101.

15. Möhl BS, Chen J, Sathiyamoorthy K, Jardetzky TS, Longnecker R. Structural and Mechanistic Insights into the Tropism of Epstein-Barr Virus. Mol Cells. 2016;39:286-91. https://doi.org/10.14348/molcells.2016.0066.

16. Temple RM, Zhu J, Budgeon L, Christensen ND, Meyers C, Sample CE. Efficient replication of Epstein-Barr virus in stratified epithelium in vitro. Proc Natl Acad Sci U S A. 2014;111:16544-9. https://doi.org/10.1073/pnas.1400818111.

17. Temple RM, Meyers C, Sample CE. Generation and Infection of Organotypic Cultures with Epstein-Barr Virus. Methods Mol Biol. 2017;1532:65-78. https:// doi.org/10.1007/978-1-4939-6655-4_4.

18. Tsang CM, Deng W, Yip YL, Zeng MS, Lo KW, Tsao SW. Epstein-Barr virus infection and persistence in nasopharyngeal epithelial cells. Chin J Cancer. 2014;33:549-55. https://doi.org/10.5732/cjc.014.10169.

19. Kikuchi K, Noguchi Y, de Rivera MW, Hoshino M, Sakashita H, Yamada T, et al. Detection of Epstein-Barr virus genome and latent infection gene expression in normal epithelia, epithelial dysplasia, and squamous cell carcinoma of the oral cavity. Tumour Biol. 2016;37:3389-404. https://doi. org/10.1007/s13277-015-4167-7.

20. Sixbey JW, Vesterinen EH, Nedrud JG, Raab-Traub N, Walton LA, Pagano JS. Replication of Epstein-Barr virus in human epithelial cells infected in vitro. Nature. 1983;306:480-3. https://doi.org/10.1038/306480a0.

21. Pegtel DM, Middeldorp J, Thorley-Lawson DA. Epstein-Barr virus infection in ex vivo tonsil epithelial cell cultures of asymptomatic carriers. J Virol. 2004; 78:12613-24. https://doi.org/10.1128/JVI.78.22.12613-12624.2004.

22. Miller N, Hutt-Fletcher LM. Epstein-Barr virus enters B cells and epithelial cells by different routes. J Virol. 1992;66:3409-14. https://doi.org/10.1128/JVI. 66.6.3409-3414.1992

23. Fingeroth JD, Weis JJ, Tedder TF, Strominger JL, Biro PA, Fearon DT. EpsteinBarr virus receptor of human B lymphocytes is the C3d receptor CR2. Proc Natl Acad Sci U S A. 1984:81:4510-4.

24. Wang $X$, Hutt-Fletcher LM. Epstein-Barr virus lacking glycoprotein gp42 can bind to B cells but is not able to infect. J Virol. 1998;72: 158-63.

25. Wang X, Kenyon WJ, Li Q, Müllberg J, Hutt-Fletcher LM. Epstein-Barr virus uses different complexes of glycoproteins $\mathrm{gH}$ and $\mathrm{gL}$ to infect $\mathrm{B}$ lymphocytes and epithelial cells. J Virol. 1998:72:5552-8.

26. Chesnokova LS, Nishimura SL, Hutt-Fletcher LM. Fusion of epithelial cells by Epstein-Barr virus proteins is triggered by binding of viral glycoproteins gHgL to integrins alphavbeta6 or alphavbeta8. Proc Natl Acad Sci U S A. 2009;106:20464-9. https://doi.org/10.1073/pnas.0907508106.

27. Chen J, Sathiyamoorthy K, Zhang X, Schaller S, Perez White BE, Jardetzky TS, et al. Ephrin receptor A2 is a functional entry receptor for Epstein-Barr virus. Nat Microbiol. 2018;3:172-80. https://doi.org/10.1038/ s41564-017-0081-7.

28. Zhang $\mathrm{H}$, Li Y, Wang HB, Zhang $\mathrm{A}$, Chen ML, Fang ZX, et al. Ephrin receptor $\mathrm{A} 2$ is an epithelial cell receptor for Epstein-Barr virus entry. Nat Microbiol. 2018;3:1-8. https://doi.org/10.1038/s41564-017-0080-8.

29. Lieberman PM. Chromatin Structure of Epstein-Barr Virus Latent Episomes. Curr Top Microbiol Immunol. 2015;390:71-102. https://doi.org/10.1007/ 978-3-319-22822-8_5.

30. Sears J, Ujihara M, Wong S, Ott C, Middeldorp J, Aiyar A. The amino terminus of Epstein-Barr Virus (EBV) nuclear antigen 1 contains AT hooks that facilitate the replication and partitioning of latent EBV genomes by tethering them to cellular chromosomes. J Virol. 2004;78:11487-505. https:// doi.org/10.1128/JVI.78.21.11487-11505.2004.

31. Tsai K, Thikmyanova N, Wojcechowskyj JA, Delecluse HJ, Lieberman PM. EBV tegument protein BNRF1 disrupts DAXX-ATRX to activate viral early gene transcription. PLoS Pathog. 2011;7:e1002376. https://doi.org/10.1371/journal. ppat.1002376

32. Rooney CM, Rowe DT, Ragot T, Farrell PJ. The spliced BZLF1 gene of Epstein-Barr virus (EBV) transactivates an early EBV promoter and induces the virus productive cycle. J Virol. 1989:63:3109-16.

33. Dharnidharka VR, Webster AC, Martinez OM, Preiksaitis JK, Leblond V, Choquet S. Post-transplant lymphoproliferative disorders. Nat Rev Dis Primers. 2016;2:15088. https://doi.org/10.1038/nrdp.2015.88.

34. Shannon-Lowe C, Rickinson A. The Global Landscape of EBV-Associated Tumors. Front Oncol. 2019;9:713. https://doi.org/10.3389/fonc.2019.00713. 
35. Thorley-Lawson DA. EBV Persistence--Introducing the Virus. Curr Top Microbiol Immunol. 2015;390:151-209. https://doi.org/10.1007/978-3-319-22 822-8_8.

36. Yang J, Liu Z, Zeng B, Hu G, Gan R. Epstein-Barr virus-associated gastric cancer: A distinct subtype. Cancer Lett. 2020;495:191-9. https://doi.org/10.1 016/j.canlet.2020.09.019.

37. Hau PM, Lung HL, Wu M, Tsang CM, Wong KL, Mak NK, et al. Targeting Epstein-Barr Virus in Nasopharyngeal Carcinoma. Front Oncol. 2020;10:600. https://doi.org/10.3389/fonc.2020.00600.

38. Hardwick JM, Lieberman PM, Hayward SD. A new Epstein-Barr virus transactivator, $R$, induces expression of a cytoplasmic early antigen. J Virol. 1988;62:2274-84

39. Buettner M, Lang A, Tudor CS, Meyer B, Cruchley A, Barros MH, et al. Lytic Epstein-Barr virus infection in epithelial cells but not in B-lymphocytes is dependent on Blimp1. J Gen Virol. 2012;93:1059-64. https://doi.org/10.1099/ vir.0.038661-0.

40. Jenkins PJ, Binné UK, Farrell PJ. Histone acetylation and reactivation of Epstein-Barr virus from latency. J Virol. 2000;74:710-20.

41. Li H, Liu S, Hu J, Luo X, Li N. M Bode, A.; Cao, Y. Epstein-Barr virus lytic reactivation regulation and its pathogenic role in carcinogenesis. Int J Biol Sci. 2016;12:1309-18. https://doi.org/10.7150/ijbs.16564.

42. Church TM, Verma D, Thompson J, Swaminathan S. Efficient Translation of Epstein-Barr Virus (EBV) DNA Polymerase Contributes to the Enhanced Lytic Replication Phenotype of M81 EBV. J Virol. 2018;92. https://doi.org/10.1128/ JVI.01794-17.

43. Neuhierl B, Delecluse HJ. The Epstein-Barr virus BMRF1 gene is essential for lytic virus replication. J Virol. 2006;80:5078-81. https://doi.org/10.1128/JVl. 80.10.5078-5081.2006.

44. Thierry E, Brennich M, Round A, Buisson M, Burmeister WP, Hutin S. Production and characterisation of Epstein-Barr virus helicase-primase complex and its accessory protein BBLF2/3. Virus Genes. 2015;51:171-81. https://doi.org/10.1007/s11262-015-1233-6.

45. Fujii K, Yokoyama N, Kiyono T, Kuzushima K, Homma M, Nishiyama Y, et al. The Epstein-Barr virus pol catalytic subunit physically interacts with the BBLF4-BSLF1-BBLF2/3 complex. J Virol. 2000;74:2550-7.

46. Hammerschmidt W, Sugden B. Identification and characterization of orilyt, a lytic origin of DNA replication of Epstein-Barr virus. Cell. 1988;55:427-33.

47. Tsurumi T. Primer terminus recognition and highly processive replication by Epstein-Barr virus DNA polymerase. Biochem J. 1991;280(Pt 3):703-8.

48. Wu L, Li C, Pan L. Nasopharyngeal carcinoma: A review of current updates. Exp Ther Med. 2018;15:3687-92. https://doi.org/10.3892/etm.2018.5878.

49. Carioli G, Negri E, Kawakita D, Garavello W, La Vecchia C, Malvezzi M. Global trends in nasopharyngeal cancer mortality since 1970 and predictions for 2020: Focus on low-risk areas. Int J Cancer. 2017;(140):2256-64. https://doi. org/10.1002/ijc.30660.

50. Brennan B. Nasopharyngeal carcinoma. Orphanet J Rare Dis. 2006;1:23. https://doi.org/10.1186/1750-1172-1-23.

51. Richardo T, Prattapong $P$, Ngernsombat $C$, Wisetyaningsih $N$, lizasa $H$, Yoshiyama $\mathrm{H}$, et al. Epstein-Barr Virus Mediated Signaling in Nasopharyngeal Carcinoma Carcinogenesis. Cancers (Basel). 2020:12. https://doi.org/10.3390/ cancers12092441.

52. Shao JY, Ernberg I, Biberfeld P, Heiden T, Zeng YX, Hu LF. Epstein-Barr virus LMP1 status in relation to apoptosis, p53 expression and leucocyte infiltration in nasopharyngeal carcinoma. Anticancer Res. 2004;24:2309-18.

53. Liu MT, Chen YR, Chen SC, Hu CY, Lin CS, Chang YT, et al. Epstein-Barr virus latent membrane protein 1 induces micronucleus formation, represses DNA repair and enhances sensitivity to DNA-damaging agents in human epithelial cells. Oncogene. 2004;23:2531-9. https://doi.org/10.1038/sj.onc.12 07375.

54. Chen Y, Zhou C, Li H, Li Y. Identifying Key Genes for Nasopharyngeal Carcinoma by Prioritized Consensus Differentially Expressed Genes Caused by Aberrant Methylation. J Cancer. 2021;12:874-84. https://doi.org/10.7150/ jca.49392.

55. Kaneda A, Matsusaka K, Aburatani H, Fukayama M. Epstein-Barr virus infection as an epigenetic driver of tumorigenesis. Cancer Res. 2012;72: 3445-50. https://doi.org/10.1158/0008-5472.CAN-11-3919.

56. Guo X, Li T, Li F, Xu Y, Wang H, Cheng W, et al. Intermittent abortive reactivation of Epstein-Barr virus during the progression of nasopharyngeal cancer as indicated by elevated antibody levels. Oral Oncol. 2019;93:85-90. https://doi.org/10.1016/j.oraloncology.201 9.04.024.
57. Martel-Renoir D, Grunewald V, Touitou R, Schwaab G, Joab I. Qualitative analysis of the expression of Epstein-Barr virus lytic genes in nasopharyngeal carcinoma biopsies. J Gen Virol. 1995;76(Pt 6):1401-8. https://doi.org/10.1099/0022-1317-76-6-1401.

58. O'Neil JD, Owen TJ, Wood VHJ, Date KL, Valentine R, Chukwuma MB, et al. Epstein-Barr virus-encoded EBNA1 modulates the AP-1 transcription factor pathway in nasopharyngeal carcinoma cells and enhances angiogenesis in vitro. J Gen Virol. 2008:89:2833-42. https://doi.org/10.1099/vir.0.2008/0033 92-0.

59. Wang L, Tian WD, Xu X, Nie B, Lu J, Liu X, et al. Epstein-Barr virus nuclear antigen 1 (EBNA1) protein induction of epithelial-mesenchymal transition in nasopharyngeal carcinoma cells. Cancer. 2014;120:363-72. https://doi.org/1 $0.1002 /$ cncr.28418

60. Li Z, Zhou Z, Wu X, Zhou Q, Liao C, Liu Y, et al. LMP1 promotes nasopharyngeal carcinoma metastasis through NTRK2-mediated anoikis resistance. Am J Cancer Res. 2020;10:2083-99.

61. Cai LM, Lyu XM, Luo WR, Cui XF, Ye YF, Yuan CC, et al. EBV-miR-BART7-3p promotes the EMT and metastasis of nasopharyngeal carcinoma cells by suppressing the tumor suppressor PTEN. Oncogene. 2015;34:2156-66. https://doi.org/10.1038/onc.2014.341.

62. Yang L, Liu L, Xu Z, Liao W, Feng D, Dong X, et al. EBV-LMP1 targeted DNAzyme enhances radiosensitivity by inhibiting tumor angiogenesis via the JNKs/HIF-1 pathway in nasopharyngeal carcinoma. Oncotarget. 2015;6: 5804-17. https://doi.org/10.18632/oncotarget.3331.

63. Ding L, Li LL, Yang J, Tao YG, Ye M, Shi Y, et al. Epstein-Barr virus encoded latent membrane protein 1 modulates nuclear translocation of telomerase reverse transcriptase protein by activating nuclear factor-kappaB p65 in human nasopharyngeal carcinoma cells. Int J Biochem Cell Biol, 2005. 37: 1881-9. https://doi.org/10.1016/j.biocel.2005.04.012.

64. Kase K, Kondo S, Wakisaka N, Dochi H, Mizokami H, Kobayashi E, et al. Epstein-Barr Virus LMP1 Induces Soluble PD-L1 in Nasopharyngeal Carcinoma. Microorganisms. 2021;9. https://doi.org/10.3390/microorga nisms9030603.

65. Jiang $R$, Cabras $G$, Sheng $W$, Zeng $Y$, Ooka $T$. Synergism of BARF1 with Ras induces malignant transformation in primary primate epithelial cells and human nasopharyngeal epithelial cells. Neoplasia. 2009;11:964-73. https:// doi.org/10.1593/neo.09706

66. Zhang Q, Luo D, Xie Z, He H, Duan Z. The Oncogenic Role of miR-BART19$3 p$ in Epstein-Barr Virus-Associated Diseases. Biomed Res Int. 2020;2020: 5217039. https://doi.org/10.1155/2020/5217039.

67. Choy EY, Siu KL, Kok KH, Lung RW, Tsang CM, To KF, et al. An Epstein-Barr virus-encoded microRNA targets PUMA to promote host cell survival. J Exp Med. 2008;205:2551-60. https://doi.org/10.1084/jem.20072581.

68. Lin C, Zong J, Lin W, Wang M, Xu Y, Zhou R, et al. EBV-miR-BART8-3p induces epithelial-mesenchymal transition and promotes metastasis of nasopharyngeal carcinoma cells through activating NF-KB and Erk1/2 pathways. J Exp Clin Cancer Res. 2018;37:283. https://doi.org/10.1186/s1304 6-018-0953-6.

69. Ferlay J, Soerjomataram I, Dikshit R, Eser S, Mathers C, Rebelo M, et al. Cancer incidence and mortality worldwide: sources, methods and major patterns in GLOBOCAN 2012. Int J Cancer. 2015;136:E359-86. https://doi. org/10.1002/ijc.29210.

70. Sandoval-Bórquez A, Saavedra K, Carrasco-Avino G, Garcia-Bloj B, Fry J, Wichmann I, et al. Noncoding Genomics in Gastric Cancer and the Gastric Precancerous Cascade: Pathogenesis and Biomarkers. Dis Markers. 2015; 2015:503762. https://doi.org/10.1155/2015/503762.

71. Yusefi AR, Bagheri Lankarani K, Bastani P, Radinmanesh M, Kavosi Z. Risk Factors for Gastric Cancer: A Systematic Review. Asian Pac J Cancer Prev. 2018;19:591-603. https://doi.org/10.22034/APJCP.2018.19.3.591.

72. Burke AP, Yen TS, Shekitka KM, Sobin LH. Lymphoepithelial carcinoma of the stomach with Epstein-Barr virus demonstrated by polymerase chain reaction. Mod Pathol. 1990;3:377-80.

73. Shibata D, Weiss LM. Epstein-Barr virus-associated gastric adenocarcinoma. Am J Pathol. 1992;140:769-74.

74. Chen XZ, Chen H, Castro FA, Hu JK, Brenner H. Epstein-Barr virus infection and gastric cancer: a systematic review. Medicine (Baltimore). 2015;94:e792. https://doi.org/10.1097/MD.0000000000000792.

75. Ribeiro J, Oliveira C, Malta M, Sousa H. Epstein-Barr virus gene expression and latency pattern in gastric carcinomas: a systematic review. Future Oncol. 2017;13:567-79. https://doi.org/10.2217/fon-2 016-0475. 
76. Wang A, Zhang W, Jin M, Zhang J, Li S, Tong F, et al. Differential expression of EBV proteins LMP1 and BHFR1 in EBV-associated gastric and nasopharyngeal cancer tissues. Mol Med Rep. 2016;13:4151-8. https://doi. org/10.3892/mmr.2016.5087.

77. Chang KC, Huang GC, Jones D, Tsao CJ, Lee JY, Su IJ. Distribution and prognosis of WHO lymphoma subtypes in Taiwan reveals a low incidence of germinal-center derived tumors. Leuk Lymphoma. 2004;45:1375-84. https://doi.org/10.1080/10428194042000198849.

78. Makita S, Maruyama D, Maeshima AM, Taniguchi H, Miyamoto K, Kitahara H, et al. Clinical features and outcomes of 139 Japanese patients with Hodgkin lymphoma. Int J Hematol. 2016;104:236-44. https://doi.org/10.1007/s12185016-2007-1.

79. Meng J, Chang C, Pan H, Zhu F, Xiao Y, Liu T, et al. Epidemiologic characteristics of malignant lymphoma in Hubei, China: A single-center 5year retrospective study. Medicine (Baltimore). 2018;97:e12120. https://doi. org/10.1097/MD.0000000000012120.

80. Piris MA, Medeiros $L$, Chang KC. Hodgkin lymphoma: a review of pathological features and recent advances in pathogenesis. Pathology. 2020;52:154-65. https://doi.org/10.1016/.jpathol.2019.09.005.

81. Küppers R. The biology of Hodgkin's lymphoma. Nat Rev Cancer. 2009;9:1527. https://doi.org/10.1038/nrc2542.

82. Ambinder RF, Browning PJ, Lorenzana I, Leventhal BG, Cosenza H, Mann RB, et al. Epstein-Barr virus and childhood Hodgkin's disease in Honduras and the United States. Blood. 1993;81:462-7.

83. Chang KC, Khen NT, Jones D, Su IJ. Epstein-Barr virus is associated with all histological subtypes of Hodgkin lymphoma in Vietnamese children with special emphasis on the entity of lymphocyte predominance subtype. Hum Pathol. 2005;36:747-55. https://doi.org/10.1016/j.humpath.2005.05.003.

84. Schrader A, Bentink S, Spang R, Lenze D, Hummel M, Kuo M, et al. High Myc activity is an independent negative prognostic factor for diffuse large B cell lymphomas. Int J Cancer. 2012;131:E348-61. https://doi.org/10.1002/ijc.2 6423.

85. Graham BS, Lynch DT. Burkitt Lymphoma. In: StatPearls [Internet]. Treasure Island (FL): StatPearls Publishing; 2021.

86. Chabay P, Lens D, Hassan R, Rodríguez Pinilla SM, Valvert Gamboa F, Rivera I, et al. Lymphotropic Viruses EBV, KSHV and HTLV in Latin America: Epidemiology and Associated Malignancies. A Literature-Based Study by the RIAL-CYTED. Cancers (Basel). 2020:12. https://doi.org/10.3390/cancers 12082166.

87. Magrath IT. African Burkitt's lymphoma. History, biology, clinical features, and treatment. Am J Pediatr Hematol Oncol. 1991;13:222-46.

88. Gastwirt JP, Roschewski M. Management of adults with Burkitt lymphoma. Clin Adv Hematol Oncol. 2018;16:812-22.

89. Linch DC. Burkitt lymphoma in adults. Br J Haematol. 2012;156:693-703. https://doi.org/10.1111/j.1365-2141.2011.08877.x.

90. Mbulaiteye SM, Anderson WF, Ferlay J, Bhatia K, Chang C, Rosenberg PS, et al. Pediatric, elderly, and emerging adult-onset peaks in Burkitt's lymphoma incidence diagnosed in four continents, excluding Africa. Am J Hematol. 2012;87:573-8. https://doi.org/10.1002/ajh.23187.

91. Dunleavy K, Little RF, Wilson WH. Update on Burkitt Lymphoma. Hematol Oncol Clin North Am. 2016;30:1333-43. https//doi.org/10.1016/.j.hoc.2016.07.009.

92. Mbulaiteye SM, Anderson WF, Bhatia K, Rosenberg PS, Linet MS, Devesa SS. Trimodal age-specific incidence patterns for Burkitt lymphoma in the United States, 1973-2005. Int J Cancer. 2010;126:1732-9. https://doi.org/10.1002/ ijc.24934.

93. Casulo C, Friedberg JW. Burkitt lymphoma- a rare but challenging lymphoma. Best Pract Res Clin Haematol. 2018;31:279-84. https://doi.org/1 0.1016/j.beha.2018.07.013.

94. Moormann AM, Bailey JA. Malaria - how this parasitic infection aids and abets EBV-associated Burkitt lymphomagenesis. Curr Opin Virol. 2016;20:7884. https://doi.org/10.1016/j.coviro.2016.09.006.

95. Choi SJ, Jung SW, Huh S, Cho H, Kang H. Phylogenetic comparison of Epstein-Barr virus genomes. J Microbiol. 2018;56:525-33. https://doi.org/10.1 007/s12275-018-8039-x.

96. Quintana MDP, Smith-Togobo C, Moormann A, Hviid L. Endemic Burkitt lymphoma - an aggressive childhood cancer linked to Plasmodium falciparum exposure, but not to exposure to other malaria parasites. APMIS. 2020;128:129-35. https://doi.org/10.1111/apm.13018.

97. Ferla V, Rossi FG, Goldaniga MC, Baldini L. Biological Difference Between Epstein-Barr Virus Positive and Negative Post-transplant Lymphoproliferative Disorders and Their Clinical Impact. Front Oncol. 2020;10:506. https://doi. org/10.3389/fonc.2020.00506.
98. He Q, Zhou Y, Fu C, Zhu W, Zhou J, Liu S, et al. Lymphoepithelioma is a nonkeratinizing squamous cell carcinoma with Epstein-Barr virus infection in China. J Cancer Res Ther. 2017;13:807-12. https://doi.org/10.4103/jcrt.JCRT_2 8017.

99. Wenig BM. Lymphoepithelial-like carcinomas of the head and neck. Semin Diagn Pathol. 2015;32:74-86. https://doi.org/10.1053/j.semdp.2014.12.004.

100. Rytkönen AE, Hirvikoski PP, Salo TA. Lymphoepithelial carcinoma: two case reports and a systematic review of oral and sinonasal cases. Head Neck Pathol. 2011;5:327-34. https://doi.org/10.1007/s12105-011-0278-7.

101. Mozaffari HR, Ramezani M, Janbakhsh A, Sadeghi M. Malignant Salivary Gland Tumors and Epstein-Barr Virus (EBV) Infection: A Systematic Review and Meta-Analysis. Asian Pac J Cancer Prev. 2017;18:1201-6. https://doi. org/10.22034/APJCP.2017.18.5.1201.

102. Han AJ, Xiong M, Zong YS. Association of Epstein-Barr virus with lymphoepithelioma-like carcinoma of the lung in southern China. Am J Clin Pathol. 2000;114:220-6. https://doi.org/10.1309/148KND54-6NJX-NA61.

103. Lee JH, Kim SH, Han SH, An JS, Lee ES, Kim YS. Clinicopathological and molecular characteristics of Epstein-Barr virus-associated gastric carcinoma: a meta-analysis. J Gastroenterol Hepatol. 2009;24:354-65. https://doi.org/1 0.1111/j.1440-1746.2009.05775.x.

104. Yordanov A, Karamanliev M, Karcheva M, Konsoulova A, Vasileva-Slaveva M, Strashilov S. Single-Center Study of Lymphoepithelioma-Like Carcinoma of Uterine Cervix over a 10-Year Period. Medicina (Kaunas). 2019:55. https://doi. org/10.3390/medicina55120780.

105. Sung H, Ferlay J, Siegel RL, Laversanne M, Soerjomataram I, Jemal A, et al. Global cancer statistics 2020: GLOBOCAN estimates of incidence and mortality worldwide for 36 cancers in 185 countries. CA Cancer J Clin. 2021. https://doi.org/10.3322/caac.21660.

106. Walboomers JM, Jacobs MV, Manos MM, Bosch FX, Kummer JA, Shah KV, et al. Human papillomavirus is a necessary cause of invasive cervical cancer worldwide. J Pathol. 1999;189:12-9. https://doi.org/10.1002/(SICI)1096-9896(1 99909)189:1<12::AID-PATH431>3.0.CO;2-F.

107. Schlecht NF, Platt RW, Duarte-Franco E, Costa MC, Sobrinho JP, Prado JC, et al. Human papillomavirus infection and time to progression and regression of cervical intraepithelial neoplasia. J Natl Cancer Inst. 2003:95: 1336-43. https://doi.org/10.1093/jnci/djg037.

108. de Lima MAP, Neto PJN, Lima LPM, Gonçalves Júnior J, Teixeira Junior AG, Teodoro IPP, et al. Association between Epstein-Barr virus (EBV) and cervical carcinoma: A meta-analysis. Gynecol Oncol. 2018;148:317-28. https://doi. org/10.1016/j.ygyno.2017.10.005.

109. Sasagawa T, Shimakage M, Nakamura M, Sakaike J, Ishikawa H, Inoue M. Epstein-Barr virus (EBV) genes expression in cervical intraepithelial neoplasia and invasive cervical cancer: a comparative study with human papillomavirus (HPV) infection. Hum Pathol. 2000;31:318-26. https://doi. org/10.1016/s0046-8177(00)80245-2.

110. Khenchouche A, Sadouki N, Boudriche A, Houali K, Graba A, Ooka T, et al. Human papillomavirus and Epstein-Barr virus co-infection in cervical carcinoma in Algerian women. Virol J. 2013;10:340. https://doi.org/10.1186/1 743-422X-10-340.

111. Aguayo F, Muñoz JP, Perez-Dominguez F, Carrillo-Beltrán D, Oliva C, Calaf GM, Blanco R, Nuñez-Acurio D. High-Risk Human Papillomavirus and Tobacco Smoke Interactions in Epithelial Carcinogenesis. Cancers (Basel). 2020;12(8):2201. https://doi.org/10.3390/cancers12082201.

112. Sun YS, Zhao Z, Yang ZN, Xu F, Lu HJ, Zhu ZY, et al. Risk Factors and Preventions of Breast Cancer. Int J Biol Sci. 2017;13:1387-97. https://doi. org/10.7150/ijbs.21635.

113. Gannon OM, Antonsson A, Bennett IC, Saunders NA. Viral infections and breast cancer - A current perspective. Cancer Lett. 2018;420:182-9. https:// doi.org/10.1016/j.canlet.2018.01.076.

114. Al Hamad M, Matalka I, Al Zoubi MS, Armogida I, Khasawneh R, Al-Husaini $M$, et al. Human Mammary Tumor Virus, Human Papilloma Virus, and Epstein-Barr Virus Infection Are Associated With Sporadic Breast Cancer Metastasis. Breast Cancer (Auckl). 2020;14:1178223420976388. https://doi. org/10.1177/1178223420976388.

115. Ghaffari H, Tavakoli A, Nafissi N, Farahmand M, Ghorbani S, Moochani SS, et al. Human cytomegalovirus and Epstein-Barr virus infections in breast cancer: A molecular study on Iranian women. Breast Dis. 2021. https://doi. org/10.3233/BD-201019.

116. Khatami A, Pormohammad A, Farzi R, Saadati H, Mehrabi M, Kiani SJ, et al. Bovine Leukemia virus (BLV) and risk of breast cancer: a systematic review 
and meta-analysis of case-control studies. Infect Agent Cancer. 2020;15:48. https://doi.org/10.1186/s13027-020-00314-7.

117. Farahmand M, Monavari SH, Shoja Z, Ghaffari H, Tavakoli M, Tavakoli A. Epstein-Barr virus and risk of breast cancer: a systematic review and metaanalysis. Future Oncol. 2019;15:2873-85. https://doi.org/10.2217/fon-20190232.

118. Hu H, Luo ML, Desmedt C, Nabavi S, Yadegarynia S, Hong A, et al. EpsteinBarr Virus Infection of Mammary Epithelial Cells Promotes Malignant Transformation. EBioMedicine. 2016;9:148-60. https://doi.org/10.1016/j. ebiom.2016.05.025.

119. Arbach H, Viglasky V, Lefeu F, Guinebretière JM, Ramirez V, Bride N, et al. Epstein-Barr virus (EBV) genome and expression in breast cancer tissue: effect of EBV infection of breast cancer cells on resistance to paclitaxel (Taxol). J Virol. 2006;80:845-53. https://doi.org/10.1128/JVl.80.2.845-853.2006.

120. Sinclair AJ, Moalwi MH, Amoaten T. Is EBV Associated with Breast Cancer in Specific Geographic Locations? Cancers (Basel). 2021;13. https://doi.org/1 0.3390/cancers13040819.

121. Johnson CM, Wei C, Ensor JE, Smolenski DJ, Amos Cl, Levin B, et al. Metaanalyses of colorectal cancer risk factors. Cancer Causes Control. 2013;24: 1207-22. https://doi.org/10.1007/s10552-013-0201-5.

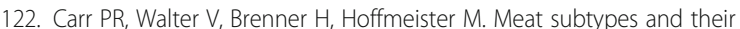
association with colorectal cancer: Systematic review and meta-analysis. Int J Cancer. 2016;138:293-302. https://doi.org/10.1002/ijc.29423.

123. Chen $H$, Chen XZ, Waterboer T, Castro FA, Brenner H. Viral infections and colorectal cancer: a systematic review of epidemiological studies. Int J Cancer. 2015;137:12-24. https://doi.org/10.1002/ijc.29180.

124. Bedri S, Sultan AA, Alkhalaf M, Al Moustafa AE, Vranic S. Epstein-Barr virus (EBV) status in colorectal cancer: a mini review. Hum Vaccin Immunother. 2019;15:603-10. https://doi.org/10.1080/21645515.2018.1543525.

125. Gupta I, Al Farsi H, Jabeen A, Skenderi F, Al-Thawadi H, AlAhmad YM, et al. High-Risk Human Papillomaviruses and Epstein-Barr Virus in Colorectal Cancer and Their Association with Clinicopathological Status. Pathogens. 2020;9. https://doi.org/10.3390/pathogens9060452.

126. Karpinski P, Myszka A, Ramsey D, Kielan W, Sasiadek MM. Detection of viral DNA sequences in sporadic colorectal cancers in relation to $\mathrm{CpG}$ island methylation and methylator phenotype. Tumour Biol. 2011;32:653-9. https://doi.org/10.1007/s13277-011-0165-6.

127. Morales-Sánchez A, Fuentes-Panana EM. The Immunomodulatory Capacity of an Epstein-Barr Virus Abortive Lytic Cycle: Potential Contribution to Viral Tumorigenesis. Cancers (Basel). 2018:10. https://doi.org/10.3390/cancers 10040098.

128. Cochet C, Martel-Renoir D, Grunewald V, Bosq J, Cochet G, Schwaab G, et al. Expression of the Epstein-Barr virus immediate early gene, BZLF1, in nasopharyngeal carcinoma tumor cells. Virology. 1993;197:358-65. https:// doi.org/10.1006/viro.1993.1597.

129. Ramayanti O, Juwana H, Verkuijlen SA, Adham M, Pegtel MD, Greijer AE, et al. Epstein-Barr virus mRNA profiles and viral DNA methylation status in nasopharyngeal brushings from nasopharyngeal carcinoma patients reflect tumor origin. Int J Cancer. 2017;140:149-62. https://doi.org/10.1002/ijc.30418.

130. Rosemarie Q, Sugden B. Epstein-Barr Virus: How Its Lytic Phase Contributes to Oncogenesis. Microorganisms. 2020;8. https://doi.org/10.3390/microorga nisms8111824.

131. Münz C. Tumor Microenvironment Conditioning by Abortive Lytic Replication of Oncogenic $y$-Herpesviruses. Adv Exp Med Biol. 2020;1225: 127-35. https://doi.org/10.1007/978-3-030-35727-6_9.

132. Hong GK, Gulley ML, Feng WH, Delecluse HJ, Holley-Guthrie E, Kenney SC Epstein-Barr virus lytic infection contributes to lymphoproliferative disease in a SCID mouse model. J Virol. 2005;79:13993-4003. https://doi.org/10.112 8/JVI.79.22.13993-14003.2005.

133. Ma SD, Yu X, Mertz JE, Gumperz JE, Reinheim E, Zhou Y, et al. An EpsteinBarr Virus (EBV) mutant with enhanced BZLF1 expression causes lymphomas with abortive lytic EBV infection in a humanized mouse model. J Virol. 2012; 86:7976-87. https://doi.org/10.1128/JVI.00770-12.

134. Chang Y, Tung CH, Huang YT, Lu J, Chen JY, Tsai CH. Requirement for cellto-cell contact in Epstein-Barr virus infection of nasopharyngeal carcinoma cells and keratinocytes. J Virol. 1999;73:8857-66.

135. Wu CC, Liu MT, Chang YT, Fang CY, Chou SP, Liao HW, et al. Epstein-Barr virus DNase (BGLF5) induces genomic instability in human epithelial cells. Nucleic Acids Res. 2010:38, 1932-1949. https://doi.org/10.1093/nar/gkp1169.

136. Chiu SH, Wu CC, Fang CY, Yu SL, Hsu HY, Chow YH, et al. Epstein-Barr virus BALF3 mediates genomic instability and progressive malignancy in nasopharyngeal carcinoma. Oncotarget. 2014;5:8583-601. https://doi.org/1 0.18632 /oncotarget.2323

137. Humans, I.W.G.o.t.E.o.C.R.t. Tobacco smoke and involuntary smoking. IARC Monogr Eval Carcinog Risks Hum 2004, 83, 1-1438.

138. Jethwa AR, Khariwala SS. Tobacco-related carcinogenesis in head and neck cancer. Cancer Metastasis Rev. 2017;36:411-23. https://doi.org/10.1007/s1 0555-017-9689-6.

139. Phillips DH, Venitt S. DNA and protein adducts in human tissues resulting from exposure to tobacco smoke. Int J Cancer. 2012;131:2733-53. https:// doi.org/10.1002/ijc.27827.

140. Huang RY, Chen GG. Cigarette smoking, cyclooxygenase-2 pathway and cancer. Biochim Biophys Acta. 1815;2011:158-69. https://doi.org/10.1016/j. bbcan.2010.11.005.

141. Chen RJ, Chang LW, Lin P, Wang YJ. Epigenetic effects and molecular mechanisms of tumorigenesis induced by cigarette smoke: an overview. J Oncol. 2011;2011:654931. https://doi.org/10.1155/2011/654931.

142. Liu X, Baecker A, Wu M, Zhou JY, Yang J, Han RQ, et al. Interaction between tobacco smoking and hepatitis $B$ virus infection on the risk of liver cancer in a Chinese population. Int J Cancer. 2018;142:1560-7. https://doi.org/10.1002/ ijc.31181.

143. Hassan MM, Spitz MR, Thomas MB, El-Deeb AS, Glover KY, Nguyen NT, et al. Effect of different types of smoking and synergism with hepatitis $C$ virus on risk of hepatocellular carcinoma in American men and women: case-control study. Int J Cancer. 2008:123, 1883-1891. https://doi.org/10.1002/ijc.23730.

144. Camargo MC, Koriyama C, Matsuo K, Kim WH, Herrera-Goepfert R, Liao LM, et al. Case-case comparison of smoking and alcohol risk associations with Epstein-Barr virus-positive gastric cancer. Int J Cancer. 2014;134:948-53. https://doi.org/10.1002/ijc.28402.

145. Chang ET, Liu Z, Hildesheim A, Liu Q, Cai Y, Zhang Z, et al. Active and Passive Smoking and Risk of Nasopharyngeal Carcinoma: A PopulationBased Case-Control Study in Southern China. Am J Epidemiol. 2017;185: 1272-80. https://doi.org/10.1093/aje/kwx018.

146. Lin JH, Jiang CQ, Ho SY, Zhang WS, Mai ZM, Xu L, et al. Smoking and nasopharyngeal carcinoma mortality: a cohort study of 101,823 adults in Guangzhou. China. BMC Cancer. 2015;15:906. https://doi.org/10.1186/s12 885-015-1902-9.

147. Xu FH, Xiong D, Xu YF, Cao SM, Xue WQ, Qin HD, et al. An epidemiological and molecular study of the relationship between smoking, risk of nasopharyngeal carcinoma, and Epstein-Barr virus activation. J Natl Cancer Inst. 2012;104:1396-410. https://doi.org/10.1093/jnci/djs320.

148. Glaser SL, Keegan TH, Clarke CA, Darrow LA, Gomez SL, Dorfman RF, et al. Smoking and Hodgkin lymphoma risk in women United States. Cancer Causes Control. 2004;15:387-97. https://doi.org/10.1023/B:CACO.0000027497. 00558.e2.

149. Bakkalci D, Jia Y, Winter JR, Lewis JE, Taylor GS, Stagg HR. Risk factors for Epstein Barr virus-associated cancers: a systematic review, critical appraisal, and mapping of the epidemiological evidence. J Glob Health. 2020;10: 010405. https://doi.org/10.7189/jogh.10.010405.

150. Hsu WL, Chien YC, Huang YT, Yu KJ, Ko JY, Lin CY, et al. Cigarette smoking increases the risk of nasopharyngeal carcinoma through the elevated level of IgA antibody against Epstein-Barr virus capsid antigen: A mediation analysis. Cancer Med. 2020:9, 1867-1876. https://doi.org/10.1002/cam4.2832.

151. Okekpa SI, S M N Mydin RB, Mangantig E, Azmi NSA, Zahari SNS, Kaur G, et al. Nasopharyngeal Carcinoma (NPC) Risk Factors: A Systematic Review and Meta-Analysis of the Association with Lifestyle, Diets, Socioeconomic and Sociodemographic in Asian Region. Asian Pac J Cancer Prev. 2019;20: 3505-14. https://doi.org/10.31557/APJCP.2019.20.11.3505.

152. Long M, Fu Z, Li P, Nie Z. Cigarette smoking and the risk of nasopharyngeal carcinoma: a meta-analysis of epidemiological studies. BMJ Open. 2017;7: e016582. https://doi.org/10.1136/bmjopen-2017-016582.

153. Zhou T, Yang DW, He YQ, Xue WQ, Liao Y, Zheng MQ, et al. Associations between environmental factors and serological Epstein-Barr virus antibodies in patients with nasopharyngeal carcinoma in South China. Cancer Med. 2019;8:4852-66. https://doi.org/10.1002/cam4.2348.

154. Hu T, Lin CY, Xie SH, Chen GH, Lu YQ, Ling W, et al. Smoking can increase nasopharyngeal carcinoma risk by repeatedly reactivating Epstein-Barr Virus: An analysis of a prospective study in southern China. Cancer Med. 2019;8: 2561-71. https://doi.org/10.1002/cam4.2083.

155. He YQ, Xue WQ, Xu FH, Xu YF, Zhang JB, Yu HL, et al. The Relationship Between Environmental Factors and the Profile of Epstein-Barr Virus Antibodies in the Lytic and Latent Infection Periods in Healthy Populations 
from Endemic and Non-Endemic Nasopharyngeal Carcinoma Areas in China. EBioMedicine. 2018;30:184-91. https://doi.org/10.1016/j.ebiom.2018. 02.019 .

156. Yang QY, He YQ, Xue WQ, Zhou T, Liao Y, Zheng MQ, et al. Association Between Serum Cotinine Level and Serological Markers of Epstein-Barr Virus in Healthy Subjects in South China Where Nasopharyngeal Carcinoma Is Endemic. Front Oncol. 2019;9:865. https://doi.org/10.3389/fonc.2019.00865.

157. Chen Y, Xu Y, Zhao W, Xiao X, Zhou X, Lin L, et al. Lack of association between cigarette smoking and Epstein Barr virus reactivation in the nasopharynx in people with elevated EBV IgA antibody titres. BMC Cancer. 2018;18:190. https://doi.org/10.1186/s12885-018-4110-6.

158. Pathmanathan R, Prasad U, Sadler R, Flynn K, Raab-Traub N. Clonal proliferations of cells infected with Epstein-Barr virus in preinvasive lesions related to nasopharyngeal carcinoma. N Engl J Med. 1995;333:693-8. https://doi.org/10.1056/NEJM199509143331103.

159. Young LS, Rickinson AB. Epstein-Barr virus: 40 years on. Nat Rev Cancer. 2004;4:757-68. https://doi.org/10.1038/nrc1452.

160. Wei L, Griego AM, Chu M, Ozbun MA. Tobacco exposure results in increased E6 and E7 oncogene expression, DNA damage and mutation rates in cells maintaining episomal human papillomavirus 16 genomes. Carcinogenesis. 2014:35:2373-81. https://doi.org/10.1093/carcin/bgu156.

161. Pena N, Carrillo D, Munoz JP, Chnaiderman J, Urzua U, Leon O, et al. Tobacco Smoke Activates Human Papillomavirus 16 p97 Promoter and Cooperates with High-Risk E6/E7 for Oxidative DNA Damage in Lung Cells. Plos One. 2015;10. https://doi.org/10.1371/journal.pone.0123029.

162. Tsang CM, Yip YL, Lo KW, Deng W, To KF, Hau PM, et al. Cyclin D1 overexpression supports stable EBV infection in nasopharyngeal epithelial cells. Proc Natl Acad Sci U S A. 2012;109:E3473-82. https://doi.org/10.1073/ pnas. 1202637109.

163. Lo KW, Chung GT, To KF. Deciphering the molecular genetic basis of NPC through molecular, cytogenetic, and epigenetic approaches. Semin Cancer Biol. 2012;22:79-86. https://doi.org/10.1016/j.semcancer.2011.12.011.

164. Lo KW, Huang DP, Lau KM. p16 gene alterations in nasopharyngeal carcinoma. Cancer Res. 1995;55:2039-43.

165. Prueitt RL, Goodman JE, Valberg PA. Radionuclides in cigarettes may lead to carcinogenesis via p16(INK4a) inactivation. J Environ Radioact. 2009;100:15761. https://doi.org/10.1016/j.jenvrad.2008.11.008.

166. Guzman LM, Koriyama C, Akiba S, Eizuru Y, Castillo D, Corvalan A, et al. High frequency of p16 promoter methylation in non-small cell lung carcinomas from Chile. Biol Res. 2007:40:365-72. S0716-97602007000400011.

167. von Zeidler SV, Miracca EC, Nagai MA, Birman EG. Hypermethylation of the p16 gene in normal oral mucosa of smokers. Int J Mol Med. 2004;14:807-11. https://doi.org/10.3892/ijmm.14.5.807.

168. Xu J, Gimenez-Conti IB, Cunningham JE, Collet AM, Luna MA, Lanfranchi HE, et al. Alterations of p53, cyclin D1, Rb, and $\mathrm{H}$-ras in human oral carcinomas related to tobacco use. Cancer. 1998;83:204-12. https://doi.org/10.1002/ (sici) 1097-0142(19980715)83:2<204:aid-cncr2>3.0.co;2-q.

169. Suzuki S, Cohen SM, Arnold LL, Pennington KL, Kato H, Naiki T, et al. Cotinine, a major nicotine metabolite, induces cell proliferation on urothelium in vitro and in vivo. Toxicology. 2020;429:152325. https://doi. org/10.1016/j.tox.2019.152325.

170. Calaf GM, Echiburú-Chau C. Synergistic effect of malathion and estrogen on mammary gland carcinogenesis. Oncol Rep. 2012;28:640-6. https://doi.org/1 0.3892/or.2012.1817

171. Calaf GM, Bleak TC, Muñoz JP, Aguayo F. Markers of epithelial-mesenchymal transition in an experimental breast cancer model induced by organophosphorous pesticides and estrogen. Oncol Lett. 2020;20:84. https:// doi.org/10.3892/ol.2020.11945.

172. Navaranjan G, Hohenadel K, Blair A, Demers PA, Spinelli JJ, Pahwa P, et al. Exposures to multiple pesticides and the risk of Hodgkin lymphoma in Canadian men. Cancer Causes Control. 1661-1673;2013:24. https://doi.org/1 0.1007/s10552-013-0240-y.

173. Luo D, Zhou T, Tao Y, Feng Y, Shen X, Mei S. Exposure to organochlorine pesticides and non-Hodgkin lymphoma: a metaanalysis of observational studies. Sci Rep. 2016;6:25768. https://doi. org/10.1038/srep25768.

174. IARC Working Group on the Evaluation of Carcinogenic Risks to Humans. Some Organophosphate Insecticides and Herbicides. Lyon (FR): International Agency for Research on Cancer; 2017.

175. Calaf GM, Garrido F. Catechol estrogens as biomarkers for mammary gland cancer. Int J Oncol. 2011;39:177-83. https://doi.org/10.3892/ijo.2011.1008.
176. Muñoz JP, Bleak TC, Calaf GM. Glyphosate and the key characteristics of an endocrine disruptor: A review. Chemosphere. 2020;128619. https://doi.org/1 0.1016/j.chemosphere.2020.128619.

177. Zhao L, Xie F, Wang TT, Liu MY, Li JL, Shang L, et al. Chlorpyrifos Induces the Expression of the Epstein-Barr Virus Lytic Cycle Activator BZLF-1 via Reactive Oxygen Species. Oxid Med Cell Longev. 2015;2015:309125. https:// doi.org/10.1155/2015/309125

178. Hardell E, Eriksson M, Lindström G, Van Bavel B, Linde A, Carlberg M, et al. Case-control study on concentrations of organohalogen compounds and titers of antibodies to Epstein-Barr virus antigens in the etiology of nonHodgkin lymphoma. Leuk Lymphoma. 2001;42:619-29. https://doi.org/10.31 09/10428190109099322.

179. Hardell L, Eriksson M. A case-control study of non-Hodgkin lymphoma and exposure to pesticides. Cancer. 1999:85:1353-60. https://doi.org/10.1002/ (sici) 1097-0142(19990315)85:6<1353::aid-cncr19>3.0.co;2-1.

180. Hardell $L$, Lindström $G$, van Bavel B, Hardell $K$, Linde A, Carlberg M, et al. Adipose tissue concentrations of dioxins and dibenzofurans, titers of antibodies to Epstein-Barr virus early antigen and the risk for non-Hodgkin lymphoma. Environ Res. 2001;87:99-107. https://doi.org/10.1006/enrs.2 001.4295 .

181. Nordström $M$, Hardell L, Lindström G, Wingfors $H$, Hardell K, Linde A. Concentrations of organochlorines related to titers to Epstein-Barr virus early antigen IgG as risk factors for hairy cell leukemia. Environ Health Perspect. 2000;108:441-5. https://doi.org/10.1289/ehp.108-1638040.

182. Harabuchi Y, Yamanaka N, Kataura A, Imai S, Kinoshita T, Mizuno F, et al. Epstein-Barr virus in nasal T-cell lymphomas in patients with lethal midline granuloma. Lancet. 1990;335:128-30. https://doi.org/10.1016/0140-673 6(90)90002-m

183. Kanavaros P, Lescs MC, Brière J, Divine M, Galateau F, Joab I, et al. Nasal Tcell lymphoma: a clinicopathologic entity associated with peculiar phenotype and with Epstein-Barr virus. Blood. 1993;81:2688-95.

184. Medeiros LJ, Jaffe ES, Chen YY, Weiss LM. Localization of Epstein-Barr viral genomes in angiocentric immunoproliferative lesions. Am J Surg Pathol. 1992;16:439-47. https://doi.org/10.1097/00000478-199205000-00002

185. Weiss LM, Gaffey MJ, Chen YY, Frierson HF. Frequency of Epstein-Barr viral DNA in "Western" sinonasal and Waldeyer's ring non-Hodgkin's lymphomas. Am J Surg Pathol. 1992;16:156-62. https://doi.org/10.1097/00000478-199202 000-00008.

186. Xu JX, Hoshida Y, Yang WI, Inohara H, Kubo T, Kim GE, et al. Life-style and environmental factors in the development of nasal NK/T-cell lymphoma: a case-control study in East Asia. Int J Cancer. 2007;120:406-10. https://doi. org/10.1002/ij. 22313 .

187. Ayee R, Ofori MEO, Wright E, Quaye O. Epstein Barr Virus Associated Lymphomas and Epithelia Cancers in Humans. J Cancer. 2020;11:1737-50. https://doi.org/10.7150/jca.37282.

188. Rudant J, Menegaux F, Leverger G, Baruchel A, Nelken B, Bertrand Y, et al. Household exposure to pesticides and risk of childhood hematopoietic malignancies: The ESCALE study (SFCE). Environ Health Perspect. 2007;115: 1787-93. https://doi.org/10.1289/ehp.10596.

189. Latifovic L, Freeman LEB, Spinelli JJ, Pahwa M, Kachuri L, Blair A, et al. Pesticide use and risk of Hodgkin lymphoma: results from the North American Pooled Project (NAPP). Cancer Causes Control. 2020;31:583-99. https://doi.org/10.1007/s10552-020-01301-4.

190. Mavoungou S, Rios P, Pacquement H, Nolla M, Rigaud C, Simonin M, et al. Maternal exposure to pesticides and risk of childhood lymphoma in France: A pooled analysis of the ESCALE and ESTELLE studies (SFCE). Cancer Epidemiol. 2020;68:101797. https://doi.org/10.1016/..canep.2020.101797.

191. Bunch KJ, Kendall GM, Stiller CA, Vincent TJ, Murphy MFG. Case-control study of paternal occupational exposures and childhood lymphoma in Great Britain, 1962-2010. Br J Cancer. 2019;120:1153-61. https://doi.org/10.1 038/s41416-019-0469-7.

192. Carozza SE, Li B, Wang Q, Horel S, Cooper S. Agricultural pesticides and risk of childhood cancers. Int J Hyg Environ Health. 2009;212:186-95. https://doi. org/10.1016/j.jiheh.2008.06.002.

193. Hardell K, Carlberg M, Hardell L, Björnfoth H, Ericson Jogsten I, Eriksson M, et al. Concentrations of organohalogen compounds and titres of antibodies to Epstein-Barr virus antigens and the risk for non-Hodgkin lymphoma. Oncol Rep. 2009;21:1567-76. https://doi.org/10.3892/or_00000389.

194. Stancek D, Kosecká G, Oltman M, Keleová A, Jahnová E. Links between prolonged exposure to xenobiotics, increased incidence of hepatopathies, immunological disturbances and exacerbation of latent Epstein-Barr virus 
infections. Int J Immunopharmacol. 1995;17:321-8. https://doi.org/10.1016/ 0192-0561(95)00006-n.

195. Rifkin E, LaKind J. Dioxin bioaccumulation: key to a sound risk assessment methodology. J Toxicol Environ Health. 1991;33:103-12. https://doi.org/10.1 080/15287399109531509.

196. USEPA. Exposure and Human Health Reassessment of 2,3,7,8Tetrachlorodiobenzo-p-dioxin (TCDD) and Related Compounds (September 2000 Draft). Part I: Estimating Exposure to dioxin-like compounds. 2000b, Volume 3: Properties, environmental levels and background exposures.

197. Fernandes AR, Falandysz J. Polybrominated dibenzo-p-dioxins and furans (PBDD/Fs): Contamination in food, humans and dietary exposure. Sci Total Environ. 2020;143191. https://doi.org/10.1016/j.scitotenv.2020.143191.

198. Bertazzi PA, Bernucci I, Brambilla G, Consonni D, Pesatori AC. The Seveso studies on early and long-term effects of dioxin exposure: a review. Environ Health Perspect. 1998;106(Suppl 2):625-33. https://doi.org/10.1289/ehp.981 06625.

199. Inoue H, Mishima K, Yamamoto-Yoshida S, Ushikoshi-Nakayama R, Nakagawa Y, Yamamoto K, et al. Aryl hydrocarbon receptor-mediated induction of EBV reactivation as a risk factor for Sjögren's syndrome. J Immunol. 2012;188:4654-62. https://doi.org/10.4049/jimmunol.1101575.

200. Sorg O. AhR signalling and dioxin toxicity. Toxicol Lett. 2014;230:225-33. https://doi.org/10.1016/j.toxlet.2013.10.039.

201. Beischlag TV, Luis Morales J, Hollingshead BD, Perdew GH. The aryl hydrocarbon receptor complex and the control of gene expression. Crit Rev Eukaryot Gene Expr. 2008;18:207-50. https://doi.org/10.1615/critreveuka rgeneexpr.v18.i3.20.

202. Gutiérrez-Vázquez C, Quintana FJ. Regulation of the Immune Response by the Aryl Hydrocarbon Receptor. Immunity. 2018;48:19-33. https://doi.org/1 0.1016/j.immuni.2017.12.012.

203. Quintana FJ, Sherr DH. Aryl hydrocarbon receptor control of adaptive immunity. Pharmacol Rev. 2013;65:1148-61. https://doi.org/10.1124/pr.113. 007823

204. Stockinger B, Di Meglio P, Gialitakis M, Duarte JH. The aryl hydrocarbon receptor: multitasking in the immune system. Annu Rev Immunol. 2014;32 403-32. https://doi.org/10.1146/annurev-immunol-032713-120245.

205. Kashuba EV, Gradin K, Isaguliants M, Szekely L, Poellinger L, Klein G, et al. Regulation of transactivation function of the aryl hydrocarbon receptor by the Epstein-Barr virus-encoded EBNA-3 protein. J Biol Chem. 2006;281:121523. https://doi.org/10.1074/jbc.M509036200.

206. Hildesheim A, Levine PH. Etiology of nasopharyngeal carcinoma: a review. Epidemiol Rev. 1993;15:466-85. https://doi.org/10.1093/oxfordjournals. epirev.a036130.

207. Poirier S, Ohshima H. de-Thé, G.; Hubert, A.; Bourgade, M.C.; Bartsch, H. Volatile nitrosamine levels in common foods from Tunisia, south China and Greenland, high-risk areas for nasopharyngeal carcinoma (NPC). Int J Cancer. 1987;39:293-6. https://doi.org/10.1002/ijc.2910390305.

208. Zou XN, Lu SH, Liu B. Volatile N-nitrosamines and their precursors in Chinese salted fish--a possible etological factor for NPC in china. Int J Cancer. 1994;59:155-8. https://doi.org/10.1002/ijc.2910590202.

209. Bouvier G, Poirier S, Shao YM, Malaveille C, Ohshima H, Polack A, et al. Epstein-Barr virus activators, mutagens and volatile nitrosamines in preserved food samples from high-risk areas for nasopharyngeal carcinoma. IARC Sci Publ. 1991:204-9.

210. Fang CY, Huang SY, Wu CC, Hsu HY, Chou SP, Tsai CH, et al. The synergistic effect of chemical carcinogens enhances Epstein-Barr virus reactivation and tumor progression of nasopharyngeal carcinoma cells. PLoS One. 2012;7: e44810. https://doi.org/10.1371/journal.pone.0044810.

211. Feng BJ, Jalbout M, Ayoub WB, Khyatti M, Dahmoul S, Ayad M, et al. Dietary risk factors for nasopharyngeal carcinoma in Maghrebian countries. Int J Cancer. 2007;121:1550-5. https://doi.org/10.1002/ijc.22813.

212. Accardi R, Gruffat H, Sirand C, Fusil F, Gheit T, Hernandez-Vargas $H$, et al. The mycotoxin aflatoxin B1 stimulates Epstein-Barr virus-induced B-cell transformation in in vitro and in vivo experimental models. Carcinogenesis. 2015;36:1440-51. https://doi.org/10.1093/carcin/bgv142.

213. Liu L, Yang J, Ji W, Wang C. Curcumin Inhibits Proliferation of Epstein-Barr Virus-Associated Human Nasopharyngeal Carcinoma Cells by Inhibiting EBV Nuclear Antigen 1 Expression. Biomed Res Int. 2019;2019:8592921. https:// doi.org/10.1155/2019/8592921.

214. Aedo-Aguilera V, Carrillo-Beltrán D, Calaf GM, Muñoz JP, Guerrero N, Osorio $J C$, et al. Curcumin decreases epithelial-mesenchymal transition by a Pirin- dependent mechanism in cervical cancer cells. Oncol Rep. 2019;42:2139-48. https://doi.org/10.3892/or.2019.7288.

215. Gallardo M, Kemmerling U, Aguayo F, Bleak TC, Muñoz JP, Calaf GM. Curcumin rescues breast cells from epithelial-mesenchymal transition and invasion induced by anti-miR-34a. Int J Oncol. 2020;56:480-93. https://doi. org/10.3892/ijo.2019.4939.

216. Wu CC, Fang CY, Cheng YJ, Hsu HY, Chou SP, Huang SY, et al. Inhibition of Epstein-Barr virus reactivation by the flavonoid apigenin. J Biomed Sci. 2017; 24:2. https://doi.org/10.1186/s12929-016-0313-9.

\section{Publisher's Note}

Springer Nature remains neutral with regard to jurisdictional claims in published maps and institutional affiliations.
Ready to submit your research? Choose BMC and benefit from:

- fast, convenient online submission

- thorough peer review by experienced researchers in your field

- rapid publication on acceptance

- support for research data, including large and complex data types

- gold Open Access which fosters wider collaboration and increased citations

- maximum visibility for your research: over $100 \mathrm{M}$ website views per year

At BMC, research is always in progress.

Learn more biomedcentral.com/submissions 